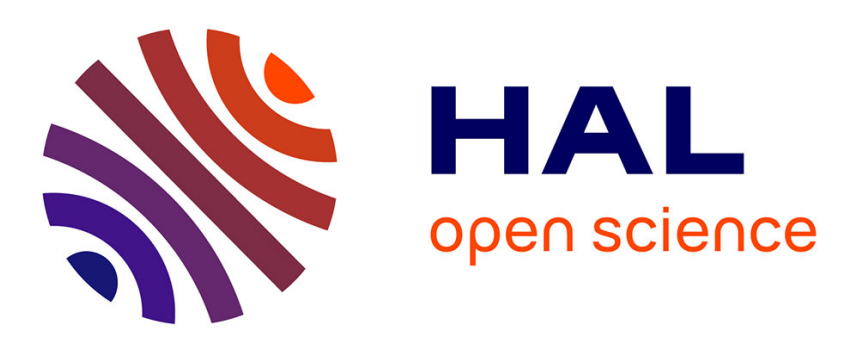

\title{
Infrared Spectroscopy of Discrete Uranyl Anion Complexes
}

Gary S Groenewold, Anita K Gianotto, Michael E Mcilwain, Michael J van Stipdonk, Michael Kullman, Travis J. Cooper, David T Moore, Nick Polfer, Jos Oomens, Ivan Infante, et al.

\section{To cite this version:}

Gary S Groenewold, Anita K Gianotto, Michael E Mcilwain, Michael J van Stipdonk, Michael Kullman, et al.. Infrared Spectroscopy of Discrete Uranyl Anion Complexes. Journal of Physical Chemistry A, 2008, 112 (3), pp.508-521. 10.1021/jp077309q · cea-02353204

\section{HAL Id: cea-02353204 https://hal-cea.archives-ouvertes.fr/cea-02353204}

Submitted on 20 Nov 2019

HAL is a multi-disciplinary open access archive for the deposit and dissemination of scientific research documents, whether they are published or not. The documents may come from teaching and research institutions in France or abroad, or from public or private research centers.
L'archive ouverte pluridisciplinaire HAL, est destinée au dépôt et à la diffusion de documents scientifiques de niveau recherche, publiés ou non, émanant des établissements d'enseignement et de recherche français ou étrangers, des laboratoires publics ou privés. 


\section{Infrared Spectroscopy of Discrete Uranyl Anion}

\section{Complexes}

Gary S. Groenewold, * Anita K. Gianotto, and Michael E. McIlwain

Idaho National Laboratory, Idaho Falls, ID, USA

Michael J. Van Stipdonk, * Michael Kullman, and Travis J. Cooper

Wichita State University, Wichita, KS, USA

David T. Moore, Nick Polfer, and Jos Oomens

FOM Instituut voor Plasmafysica Rijnhuizen, Nieuwegein, The Netherlands.

Ivan Infante, Lucas Visscher

Vrije Universiteit Amsterdam, The Netherlands

Bertrand Siboulet

DEN/DRCP/SCPS, CEA Marcoule, 30207, Bagnols-sur-Cèze cedex, France

Wibe A. de Jong

Pacific Northwest National Laboratory, Richland, WA, USA

AUTHOR ADDRESS: Idaho National Laboratory, P. O. Box 1625, Idaho Falls, ID 83415-2208

AUTHOR EMAIL ADDRESS: gary.groenewold@inl.gov

RECEIVED DATE (automatically inserted by publisher);

TITLE RUNNING HEAD: Discrete Uranyl Anion Complexes 
1 ABSTRACT: The Free-Electron Laser for Infrared Experiments (FELIX) was used to study the

2 wavelength-resolved multiple photon dissociation of discrete, gas phase uranyl $\left(\mathrm{UO}_{2}{ }^{2+}\right)$ complexes

3 containing a single anionic ligand (A), with or without ligated solvent molecules (S). The uranyl

4 antisymmetric and symmetric stretching frequencies were measured for complexes with general formula

$5 \quad\left[\mathrm{UO}_{2} \mathrm{~A}(\mathrm{~S})_{\mathrm{n}}\right]^{+}$, where A was either hydroxide, methoxide, or acetate; $\mathrm{S}$ was water, ammonia, acetone, or

6 acetonitrile; and $\mathrm{n}=0-3$. The values for the antisymmetric stretching frequency for uranyl ligated with

7 only an anion $\left(\left[\mathrm{UO}_{2} \mathrm{~A}\right]^{+}\right)$were as low or lower than measurements for $\left[\mathrm{UO}_{2}\right]^{2+}$ ligated with as many as

8 five strong neutral donor ligands, and are comparable to solution phase values. This result was

9 surprising because initial DFT calculations predicted values that were $30-40 \mathrm{~cm}^{-1}$ higher, consistent

10 with intuition but not with the data. Modification of the basis sets and use of alternative functionals

11 improved computational accuracy for the methoxide and acetate complexes, but calculated values for

12 the hydroxide were greater than the measurement regardless of the computational method used.

13 Attachment of a neutral donor ligand $\mathrm{S}$ to $\left[\mathrm{UO}_{2} \mathrm{~A}\right]^{+}$produced $\left[\mathrm{UO}_{2} \mathrm{AS}\right]^{+}$, which produced in only very

14 modest changes to the uranyl antisymmetric stretch frequency, and did not universally shift the

15 frequency to lower values. DFT calculations for $\left[\mathrm{UO}_{2} \mathrm{AS}\right]^{+}$were in accord with trends in the data, and

16 showed that attachment of the solvent was accommodated by weakening of the U-anion bond as well as

17 the uranyl. When uranyl frequencies were compared for $\left[\mathrm{UO}_{2} \mathrm{AS}\right]^{+}$species having different solvent

18 neutrals, values decreased with increasing neutral nucleophilicity.

19 KEYWORDS: IRMPD, DFT, actinide, free electron laser, coordination complex, mass spectrometry 
2 The chemical behavior of uranium in general, and the linear uranyl dication $\left[\mathrm{UO}_{2}\right]^{2+}$ in particular, is

3 diverse on account of the relative ease of redox processes, ${ }^{1}$ and the availability of $\mathrm{f}$ and $\mathrm{d}$ orbitals ${ }^{2-4}$ for 4 complex formation. The latter has a profound affect on the solubility of the element. ${ }^{5,6}$ In solution, $5 \quad\left[\mathrm{UO}_{2}\right]^{2+}$ is the dominant species, ${ }^{6-8}$ where it plays an important role in heavy element separations ${ }^{9}$ and in 6 mobility of the element in the environment. ${ }^{10}$ At low $\mathrm{pH},\left[\mathrm{UO}_{2}\right]^{2+}$ exists as the solvated dication in 7 solution with weakly complexing anions. ${ }^{10}$ Hydrolysis ${ }^{11,12}$ at higher solution $\mathrm{pH}$ values, or the presence 8 of more strongly coordinating anions, produces uranyl complexes coordinated by one or more anionic 9 ligands. $^{8,13}$

10 The chemical diversity of species has motivated research in vibrational spectroscopy and 11 computational chemistry to understand the coordination and nature of bonding in uranyl complexes 12 containing different ligands because these factors have reactivity and stability implications. ${ }^{14,15}$ Infrared

13 and Raman spectroscopy studies of $\left[\mathrm{UO}_{2}\right]^{2+}$ have shown that the respective antisymmetric $\left(\mathrm{v}_{3}\right)$ and 14 symmetric $\left(v_{1}\right)$ stretching frequencies ${ }^{16}$ act as convenient "thermometers" for gauging the electron15 donating capability of the equatorial ligand field, because the frequencies are strongly correlated with 16 the coordination environment. Nucleophilic ligands in the coordination sphere donate electron density to 17 the cationic metal center, and this spills over into the $\pi^{*}$-antibonding orbitals of the uranyl ion to cause a 18 concomitant decrease in the associated $v_{1}$ and $v_{3}$ frequencies. Increased electron density at the uranium 19 metal center can be effected by attachment of more donor ligands, ${ }^{17}$ or by increasing the nucleophilicity 20 of the ligands. ${ }^{18,19}$ Generally for a modestly complexing solution environment, $v_{3}$ values near $960 \mathrm{~cm}^{-1}$ 21 are typical, ${ }^{18}$ as originally reported by Jones and Penneman in $1953 .{ }^{20}$ However, when more strongly 22 basic ligands like hydroxide ${ }^{7,12,21,22}$ are present, the resulting complexes exhibit much lower $v_{3}$ values, 23 which have been noted in both solutions ${ }^{23,24}$ and solids. ${ }^{25-28}$ Similar trends for the symmetric $v_{1}$ stretch 24 are seen in Raman spectra ${ }^{12,15,29}$ and strong correlations between $v_{1}$ and $v_{3}$ frequencies have been 
1 established. ${ }^{30}$ Increasing the local electron density at the metal center in other ways, such as by formal

2 reduction (to $\left.\mathrm{UO}_{2}^{+}\right)^{24,31}$ or substitution of a more electron-rich metal (i.e. $\mathrm{Np}, \mathrm{Pu}, \mathrm{Am}$ ), produces a

3 similar effect. ${ }^{29,32}$

4 Computational chemistry ${ }^{2,3}$ helps provide a quantitative understanding of structure and bonding in

5 uranyl complexes. Impressive progress has been made using density functional theory (DFT), ${ }^{33-36}$ which

6 is remarkable given the theoretical difficulty of accounting for the large number of electrons, spin-orbit

7 coupling, and relativistic effects encountered in modeling uranyl molecules. ${ }^{33,35}$ The computational

8 results are strongly influenced by the choice of functional, basis set and effective core potential

9 employed. ${ }^{37,38}$ Vibrational frequencies generated using DFT $^{37,39,40}$ are invaluable because they provide a

10 basis for the interpretation of spectroscopy experiments. However, comparisons between theory and, for

11 example, solution-phase experimental studies are complicated because multiple species may be present

12 in solution ${ }^{8,41}$ as a result of rapid ligand exchange, ion pair formation, redox reactions, and solvent

13 effects. ${ }^{1,7,11,12,17,42}$ Because vibrational spectra collected from solution-phase experiments potentially

14 contain contributions from multiple species, comparisons to results produced by DFT calculations

15 (which are generated for discrete, well-defined species) are difficult. Longer-range interactions with the

16 second solvation sphere also influence the spectroscopy of the complexes, and further complicate

17 comparisons. An elegant way around this is to compare DFT results to structures determined using X-

18 ray crystallography, however the effect of neighboring molecules in the crystal lattice is a complicating

19 factor. $^{43}$

20 An alternative approach for converging vibrational spectroscopy and computational chemistry is to

21 measure the infrared spectra of discrete species isolated in the gas phase, ${ }^{44}$ which can be accomplished

22 using a trapped ion mass spectrometer (MS) (e.g., a Fourier transform ion cyclotron resonance [FT-ICR]

23 or quadrupole ion trap instrument) interfaced to a high intensity, tunable infrared source that is provided

24 by a free electron laser. ${ }^{41,44-47}$ Using electrospray ionization (ESI), ${ }^{48-51}$ a wide range of $\mathrm{UO}_{2}{ }^{2+}$ species $^{52-55}$

25 can be formed and isolated in the FT-ICR-MS. Normally, ion concentrations in the gas phase are too 
1 low to enable direct absorption measurements, but by rapid absorption of 10 s to 100 s of photons, the

2 vibrational energy of a discrete species may be raised to the point where bond cleavage occurs. ${ }^{44,56}$ In

3 this case, photon absorption is signaled by a change in ion mass, and plotting ion intensities as a

4 function of wavelength produces infrared multiple photon dissociation (IRMPD) spectra which bear

5 strong similarity to those measured using conventional absorption approaches. ${ }^{57-59}$

6 In prior research campaigns, the IRMPD strategy was used to produce spectra of discrete uranyl7 solvent complexes $\left[\mathrm{UO}_{2} \mathrm{~S}_{\mathrm{n}=2-5}\right]^{2+}$ where $\mathrm{S}=$ acetone $(\mathrm{ACO})$ and or acetonitrile (ACN). ${ }^{60}$ The uranyl $v_{3}$

8 frequency underwent systematic red shifts with serial addition of donor ligands, and with substitution of

9 a stronger nucleophilic ligand for a weaker one (e.g. ACO for ACN). Interestingly, the uranyl $v_{3}$

10 frequencies measured using IRMPD were never as low as the value for $\mathrm{UO}_{2}{ }^{2+}$ in solution, ${ }^{20}$ despite the

11 fact that the ligands in the gas-phase experiments (ACO and ACN) were stronger nucleophiles than $\mathrm{H}_{2} \mathrm{O}$

12 (the dominant ligand in solution). This observation led to conjecture that additional interactions may be

13 contributing to the observed uranyl shift in solution-phase experiments.

14 The subject of this report is the IRMPD spectroscopy of gas-phase $\left[\mathrm{UO}_{2} \mathrm{~A}\right]^{+}$species (where anion $\mathrm{A}=$ $15 \mathrm{OH}, \mathrm{OCH}_{3}$, and acetate $\left.(\mathrm{OAc})\right)$, and complexes in which $\left[\mathrm{UO}_{2} \mathrm{~A}\right]^{+}$is modified by the attachment of a 16 single neutral donor solvent $\mathrm{S}$, to form $\left[\mathrm{UO}_{2} \mathrm{AS}_{1-2}\right]^{+}$(where $\mathrm{S}=\mathrm{H}_{2} \mathrm{O}, \mathrm{NH}_{3}, \mathrm{ACN}$, or $\mathrm{ACO}$ ). The 17 hydroxide and acetate anions are representative of those commonly encountered in solution-phase 18 studies of $\mathrm{UO}_{2}{ }^{2+}$ speciation, ${ }^{61}$ and acetate and methoxide are models for functional groups expected to 19 interact with $\mathrm{UO}_{2}{ }^{2+}$ in biological and geochemical environments. The primary focus of this work is to 20 explore and understand the trends in the antisymmetric uranyl stretching frequency $\left(v_{3}\right)$, as a function of 21 the number and binding strength of the various anionic and neutral ligands, by comparing the 22 experimental IRMPD results with predictions from electronic structure calculations employing several 23 different computational methods. In general, the measured $v_{3}$ frequencies for the bare anion complexes 24 were significantly lower than the predicted computational values, and approached those measured in 25 solution for coordinatively saturated $\mathrm{UO}_{2}{ }^{2+}$. Addition of a neutral donor to form $\left[\mathrm{UO}_{2} \mathrm{AS}\right]^{+}$did not 
1 substantially alter the $v_{3}$ values compared to $\left[\mathrm{UO}_{2} \mathrm{~A}\right]^{+}$, which was surprising because prior studies

2 showed that the antisymmetric stretch is systematically red-shifted upon attachment of a donor neutral

3 ligand. Comparison of the $v_{3}$ values for different $\left[\mathrm{UO}_{2} \mathrm{AS}\right]^{+}$complexes showed a systematic decrease

4 with increasing nucleophilicity of the neutral donor S. DFT calculations also suggested that when the

5 neutral is added bonding is accommodated by weakening both the uranyl-anion bond, as well as the

6 uranyl moiety.

7 EXPERIMENTAL

8 IRMPD spectra were collected at the Free Electron Laser for Infrared eXperiments (FELIX) facility, 9 located at the FOM Instituut voor Plasmafysica 'Rijnhuizen' (Nieuwegein, The Netherlands). ${ }^{47}$ The free 10 electron laser is interfaced to a custom-built Fourier transform ion cyclotron resonance (FT-ICR) mass 11 spectrometer. ${ }^{57,62}$

12 Generation of Uranyl Complexes by Electrospray Ionization (ESI). ESI was used to generate singly13 and doubly-charged uranyl complexes. ${ }^{52,54}$ A one millimolar solution of uranyl nitrate was generated by 14 dissolving the hexahydrate salt (Fluka/Sigma-Aldrich, St. Louis, MO, USA) in water to produce uranyl 15 complexes that were introduced into the hexapole ion accumulation chamber. The ESI source 16 (Micromass, Manchester, U.K.) was operated at $3 \mathrm{kV}$ with respect to ground. Ions were generated at 17 atmospheric pressure and were extracted into vacuum using ion optics oriented orthogonally with 18 respect to the spray axis, and then gated into a hexapole ion accumulation chamber where they were 19 stored for $0.5-1.0 \mathrm{~s}$ prior to being transmitted into the FT-ICR-MS. The mass spectra observed were 20 sensitive to various temperatures, voltages and carrier-gas and solution flow rates of the ESI source. 21 Particularly important were the desolvation temperature ${ }^{54}$ (which was controlled by a heater and 22 thermocouple on the block through which the spray capillary passed) and the temperature of the 23 desolvation gas, which were maintained at 29 and $52^{\circ} \mathrm{C}$, respectively. The flow rate of the spray solution 24 was $25 \mu \mathrm{min}^{-1}$, and the desolvation gas $\left(\mathrm{N}_{2}\right.$, which ensheathed the solution spray) flow rate was 
1 maintained at $30 \mathrm{~L} \mathrm{~min}^{-1}$. Attempts to make hydrated $\left[\mathrm{UO}_{2} \mathrm{NO}_{3}\right]^{+}$were not successful because traces of

2 methanol, acetone, acetonitrile, acetic acid and ammonia in the spray chamber resulted in production of

3 hydroxide, methoxide and acetate complexes. By increasing the radio frequency power on the ion

4 accumulation hexapole, most of the ion population was converted to $\left[\mathrm{UO}_{2} \mathrm{OH}\right]^{+},\left[\mathrm{UO}_{2} \mathrm{OCH}_{3}\right]^{+}$and

$5 \quad\left[\mathrm{UO}_{2} \mathrm{OAc}\right]^{+}$; these species were also formed as complexes with a single solvent molecule (see below),

6 which provided the ensemble of species for infrared spectroscopy.

Fourier Transform Ion Cyclotron Resonance Mass Spectrometry (FT-ICR-MS), and Infrared Multiphoton Dissociation (IRMPD) $::^{46,57,59}$ Ions accumulated in the external hexapole were gated into

9 the ICR cell, where complexes identified for IRMPD were isolated using a stored waveform inverse

10 Fourier transform (SWIFT) pulse. ${ }^{63}$ This ejected all species except those having the desired mass.

11 Isolated ionic complexes were irradiated using two FELIX macropulses, which induced elimination of a

12 solvent molecule, a radical or a rearrangement product (depending on the complex) when the incident

13 wavelength matched an absorption band. The IRMPD mechanism has been described in detail

14 elsewhere. ${ }^{45,62,64}$ Briefly, it involves sequential, non-coherent absorption of many (tens to hundreds)

15 infrared photons, with each photon being "relaxed" by intramolecular vibrational redistribution (IVR)

16 before the next one is absorbed. In this way, the internal vibrational energy of the molecule can be

17 resonantly increased above the dissociation threshold, resulting in fragmentation. It has been shown that

18 the infrared spectra obtained are comparable to those obtained using linear absorption techniques. ${ }^{56,65}$

19 FELIX (60 mJ per macropulse, $5 \mu$ s pulse duration, bandwidth $0.2-0.5 \%$ of central $\lambda$ ) was scanned

20 primarily through the spectral region of interest around $10 \mu \mathrm{m}$, in increments $\leq 0.04 \mu \mathrm{m}$, after which

21 IRMPD product ions and un-dissociated precursor ions were measured using the excite/detect sequence

22 of the FT-ICR-MS. ${ }^{66,67}$ The IRMPD efficiency was then expressed as $-\log (1-[$ summed fragment ion 23 yield]), corrected for the width of the acquisition channels and linearly normalized to correct for

24 variations in FELIX power over the spectral range. Peak centers were chosen by fitting a Gaussian peak 25 to the data using Origin plotting software(version 7.5, OriginLab, Northampton, MA). Precision was 
1 not evaluated, on account of the time required for repetitive acquisition of the peak profiles, and the

2 precious nature of beam time at FELIX. Nevertheless, the precision of measurement of peak position is

3 probably on the order of a couple of $\mathrm{cm}^{-1}$, based on earlier examination of the position(s) of the

4 antisymmetric uranyl stretch and carbonyl $\mathrm{C}=\mathrm{O}$ stretch in double charged complexes. ${ }^{60}$

5 Because some of the complexes were difficult to fragment, signal-to-noise was less than desired, and

6 so the isolated complexes were subjected to multiple irradiation/acquisition sequences at each

7 wavelength across the scanned region. This lengthened acquisition time, and this factor together with the

8 need to strictly economize beam time at the FELIX FT-ICR-MS beamline constrained data acquisition

9 for most complexes to the diagnostic $\mathrm{O}=\mathrm{U}=\mathrm{O}$ antisymmetric stretch $\left(\mathrm{v}_{3}\right)$.

10 Density Functional Theory (DFT) Structure and Frequency Calculations. DFT calculations were

11 performed using several different approaches, which varied in treatment of relativistic and core

12 polarization effects, functional, basis set, and software package used. This was done to compare

13 approaches that are commonly available and executable by non-specialists with more advanced methodologies

14 that require access to substantial computational power.

15 (1) Calculations using local density approximation (LDA) with the Vosko, Wilk and Nusair (VWN)

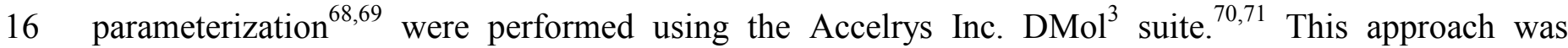

17 employed because these calculations could be readily executed and provided an instant theoretical

18 feedback on the recorded spectra. This efficiency is in large part due to use of a semi-core

19 pseudopotential $^{72}$ was applied to describe the core electrons, combined with the use of polarized

20 numerical basis sets (DNP) for the active electrons. A fine $\left(10^{-8}\right)$ energy convergence criterion was

21 employed to ensure optimal geometries and representative vibrational frequencies. With this approach it

22 was possible to calculate most structures in only a few hours using eight processors. No scaling of the

23 calculated frequencies was performed.

24 (2) DFT calculations of structures and harmonic frequencies with the more accurate hybrid B3LYP 25 functional ${ }^{73,74}$ were performed with the $\mathrm{NWChem}^{75,76}$ and Gaussian ${ }^{77}$ suite of programs. Different 
1 combinations of functionals and basis sets were employed in efforts to derive a consistent view of the

2 IRMPD phenomena measured in the context of complex structure and dissociation behavior. Uranium

3 was described by an effective core potential and its associated basis set: either the LANL2dz ECP and

4 orbital basis set $^{78}$ or the MWB60 ECP and basis set (SDD), ${ }^{83-86}$ which features Stuttgart/Dresden

5 effective core potentials were used for uranium. Other atoms in the complexes $(\mathrm{O}, \mathrm{C}, \mathrm{H}$, and $\mathrm{N})$ were

6 described using the aug-cc-pVDZ orbital basis sets, ${ }^{79}$ the D95V basis set, ${ }^{83-86}$ the all-electron $3-21 \mathrm{~g}^{*}$

7 basis sets, or the $6-31+\mathrm{g}(\mathrm{d})$ basis set. The relatively small $3-21 \mathrm{~g}$ basis (which include single first

8 polarization functions on row 2 atoms) set is generally considered to be too small for use in modeling

9 actinide molecules, but one goal of this study was to evaluate the use of the SDD/3-21g* general basis

10 set approach for interpretation of gas-phase IRMPD experiments.

11 (3) In addition NWChem was used to perform correlation corrected vibrational self consistent field 12 (cc-VSCF) calculations ${ }^{80-82}$ that provide an estimate of the effect of anharmonicity and mode-coupling

13 for the fundamental vibrational states. Starting with the vibrational self-consistent field (VSCF)

14 method, degenerate perturbation theory is used to correct for effects of correlation between different

15 vibrational modes, enabling calculation of anharmonic vibrational states for polyatomic molecules.

16 (4) Finally we also employed the ADF2006.01 ${ }^{87}$ package to quantitatively assess the donation of the 17 ligands to the uranyl moiety and to compute the energetic requirements for different dissociation 18 channels. Prior experience indicated reliable thermodynamic accuracy and thus motivated this approach.

19 Geometric parameters (structures and frequencies) were thereby determined at the scalar relativistic 20 ZORA $^{88}$-PW91 ${ }^{89}$-TZ2P level of theory using a restricted DFT and a small frozen core, while 21 fragmentation energies were computed including spin-orbit coupling terms. The charge transfer between 22 ligands and the uranyl was analyzed using both Hirshfeld charge analysis and Voronoi Deformation 23 Density (VDD) methods. The energy differences reported do not reflect energies to transition states 24 (which may be relevant for the loss of $\mathrm{H}_{2} \mathrm{O}$ from $\left[\mathrm{UO}_{2} \mathrm{OH}(\mathrm{ACO})\right]^{+}$and photo-fragmentation of $\left.25\left[\mathrm{UO}_{2} \mathrm{OCH}_{3}\right]^{+}\right)$. 
aqueous uranyl nitrate solutions modified with organic solvents had previously been shown to produce

4 dications ligated with neutral donors, provided the capillary temperature was kept close to ambient. ${ }^{54,60}$

5 However, by modestly increasing the capillary temperature and the RF power of the ion accumulation

6 hexapole, uranyl ion pairs were formed that enabled examination of their IRMPD spectra, as a

7 complement to prior measurements made for the uranyl dication bound with neutral ligands. ${ }^{60} \mathrm{~A}$

8 prominent $\left[\mathrm{UO}_{2} \mathrm{OH}\right]^{+}$ion was produced at $\mathrm{m} / \mathrm{z} 287$, and lower abundance complexes were observed at

$9 \mathrm{~m} / \mathrm{z} 345,328,305$ and 304 that correspond to $\left[\mathrm{UO}_{2} \mathrm{OH}(\mathrm{ACO})\right]^{+},\left[\mathrm{UO}_{2} \mathrm{OH}(\mathrm{ACN})\right]^{+},\left[\mathrm{UO}_{2} \mathrm{OH}\left(\mathrm{H}_{2} \mathrm{O}\right)\right]^{+}$and

$10\left[\mathrm{UO}_{2} \mathrm{OH}\left(\mathrm{NH}_{3}\right)\right]^{+}$, respectively. The ammonia, acetone, and acetonitrile were present in the hexapole

11 accumulation region of the ESI/FT-ICR instrument from prior experiments that involved the use of the

12 solvents and ammonium acetate buffer solutions. The five different hydroxide complexes that were

13 furnished by manipulation of the electrospray conditions were isolated using a SWIFT sequence, ${ }^{67}$ and

14 then photo-fragmented by scanning the free electron laser over the spectral region corresponding to the uranyl antisymmetric stretching frequency $\left(\sim 1000 \mathrm{~cm}^{-1}\right)$; the resulting IRMPD spectra are shown in

16 Figure 1.

17 Photo-fragmentation of $\left[\mathrm{UO}_{2} \mathrm{OH}\right]^{+}$resulted in reductive elimination of a hydroxyl radical, and the 18 antisymmetric uranyl $v_{3}$ stretch for this species appeared as a broadened absorption centered at $971 \mathrm{~cm}^{-1}$ 19 (Figure 1). The low abundance and profile of the peak reflected inefficient photo-fragmentation and high 20 energetic requirements: ${ }^{44}$ Calculations using ZORA-PW91-TZ2P (vide infra) indicated that the energy 21 to dissociate the complex to $\left[\mathrm{UO}_{2}\right]^{+}$and a hydroxyl radical was $96.4 \mathrm{kcal} \mathrm{mol}^{-1}$. The $\mathrm{v}_{3}$ value for $22\left[\mathrm{UO}_{2} \mathrm{OH}\right]^{+}$was lower than the most red-shifted dication complexes $\left[\mathrm{UO}_{2}(\mathrm{ACO})_{4}\right]^{2+}\left(988 \mathrm{~cm}^{-1}\right)$ and $23\left[\mathrm{UO}_{2}(\mathrm{ACN})_{5}\right]^{2+}\left(995 \mathrm{~cm}^{-1}\right)$, which suggested at first glance that a single hydroxide transfers as much or 24 more electron density to the uranium center as does four or five strong donors in a fully coordinated 25 uranyl complex. This conclusion was surprising, and in fact opposed the results of VDD analyses, that 
1 indicated a charge transfer of 0.52 e from the hydroxide to the uranyl, while the charge transfer from

2 four acetones accounted for $0.62 \mathrm{e}$.

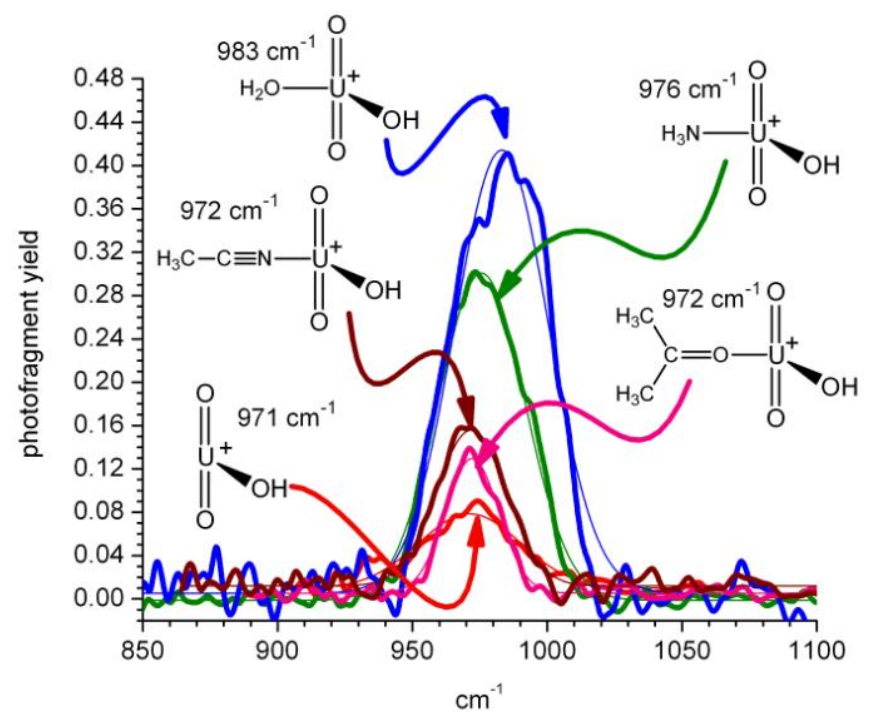

5 Figure 1. Infrared multiple photon dissociation spectra of the antisymmetric $\mathrm{O}=\mathrm{U}=\mathrm{O}$ stretching region 6 for $\left[\mathrm{UO}_{2} \mathrm{OH}\right]^{+}$and ligand complexes containing (clockwise) a single $\mathrm{ACN}, \mathrm{H}_{2} \mathrm{O}, \mathrm{NH}_{3}$, and ACO. The 7 yield values for the ACN complex were multiplied by a factor of two, to visually distinguished it from 8 the unmodified hydroxide complex.

9 The value for the $\left[\mathrm{UO}_{2} \mathrm{OH}\right]^{+}$uranyl antisymmetric stretching frequency was lower than anticipated 10 based on prior DFT calculations using B3LYP. A red shift of $183 \mathrm{~cm}^{-1}$ was calculated for $\left[\mathrm{UO}_{2}(\mathrm{OH})_{2}\right]$ 11 by Marsden and coworkers; ${ }^{40}$ subtraction of this value from $1140 \mathrm{~cm}^{-1}$ (the value calculated for 12 unligated $\left.\left[\mathrm{UO}_{2}\right]^{2+}\right)^{38}$ produces a frequency of $957 \mathrm{~cm}^{-1}$ for the bis-hydroxy complex. The measured 13 value of $971 \mathrm{~cm}^{-1}$ for the monohydroxy cannot be compared directly, because the modeled and measured 14 complexes are different. But the values are reasonably close to each other, which suggests that most of 15 the red shift results from attachment of the first $\mathrm{OH}^{-}$ligand, and that attachment of the second ligand 
1 produces a much more modest change in frequency. This trend is in qualitative agreement with very small shifts produced by attachment of neutral donors to $\left[\mathrm{UO}_{2} \mathrm{~A}\right]^{+}$complexes (vide infra).

3 The $\left[\mathrm{UO}_{2} \mathrm{OH}\right]^{+} v_{3}$ value measured in the gas phase is very close to that measured in aqueous solution 4 for $\left[\mathrm{UO}_{2}\right]^{2+}$ (960 to $965 \mathrm{~cm}^{-1}$ ), which is considered to have five inner sphere aquo ligands. ${ }^{17,18,20,90,91}$ 5 Lower values have been measured for hydroxide complexes in solution, but these have been attributed 6 to species having multiple uranyl moieties, e.g. a $v_{3}$ measurement at $\sim 940 \mathrm{~cm}^{-1}$ has been assigned to $7\left[\left(\mathrm{UO}_{2}\right)_{2}(\mathrm{OH})_{2}\right]^{2+},{ }^{17,21,92}$ and an even lower $v_{3}$ value of $923 \mathrm{~cm}^{-1}$ to $\left[\left(\mathrm{UO}_{2}\right)_{3}(\mathrm{OH})_{5}\right]^{+}$. $^{17,92}$ These $v_{3}$ 8 measurements indicate that the frequency is decreased by the presence of more than one $\mathrm{U}$ atom in the 9 complexes, but are also certainly influenced by coordinated solvent molecules.

10 The appearance of $\left[\mathrm{UO}_{2} \mathrm{OH}\right]^{+}$complexed with one or more solvent molecules enabled the effect of 11 neutral donor ligands on the antisymmetric stretching frequency to be examined. The prior study of $12 \quad\left[\mathrm{UO}_{2}\right]^{2+}$ complexes with neutral ligands ${ }^{60}$ showed that the antisymmetric stretching frequency was 13 sequentially red-shifted by the serial attachment of additional neutral donor ligands, for example in the 14 acetone (ACO) complexes $\left[\mathrm{UO}_{2}(\mathrm{ACO})_{\mathrm{n}}\right]^{2+}$, the frequency decreased from 1017 to 1000 to $988 \mathrm{~cm}^{-1}$ as n 15 went from 2 to 3 to 4 (respectively). ${ }^{60}$ The trend measured for a series of acetonitrile (ACN) complexes 16 was similar, as was the magnitude of the red shift caused by an additional donor neutral. These 17 observations led to the expectation that attachment of a neutral donor to $\left[\mathrm{UO}_{2} \mathrm{OH}\right]^{+}$would result in a 18 similar red shift.

19 Isolation and photo-fragmentation of $\left[\mathrm{UO}_{2} \mathrm{OH}(\mathrm{ACO})\right]^{+}$resulted in parallel elimination reactions: loss 20 of intact ACO, and loss of $\mathrm{H}_{2} \mathrm{O}$ (Scheme 1, Table 1). Computationally, the two pathways were found to 21 have very similar reaction energies: using ZORA-PW91-TZ2P both channels were endothermic by 41.4 $22 \mathrm{kcal} / \mathrm{mol}$, and a similar conclusion was derived using B3LYP/LANL2dz/aug-cc-pVDZ, which predicted 23 values of 46.5 and $42.6 \mathrm{kcal} / \mathrm{mol}$ for loss of $\mathrm{ACO}$ and $\mathrm{H}_{2} \mathrm{O}$ respectively. The loss of $\mathrm{H}_{2} \mathrm{O}$ involves 24 transfer of a proton from a methyl carbon on $\mathrm{ACO}$ to the hydroxide, leaving behind the acetone enolate 25 which calculations show remains coordinated through the oxygen atom. No difference in frequencies 
1 was observed in the two photo-fragment channels, which had maxima at $972 \mathrm{~cm}^{-1}$. This value was

2 effectively equal to the measurement for the unmodified $\left[\mathrm{UO}_{2} \mathrm{OH}\right]^{+}$, which initially would seem to

3 indicate that addition of the strong ACO donor had no further effect on the uranyl moiety. However, this

4 conclusion is inconsistent with the fairly strong binding predicted by the PW91 and B3LYP calculations.

5 Furthermore, the carbonyl stretching region for the $\left[\mathrm{UO}_{2} \mathrm{OH}(\mathrm{ACO})\right]^{+}$complex was scanned and an

6 absorption with a value of $1633 \mathrm{~cm}^{-1}$ was found. In our previous study of $\left[\mathrm{UO}_{2}(\mathrm{ACO})_{\mathrm{n}}\right]^{2+}$ complexes, we

7 observed that the ligand CO stretch was strongly red-shifted to $1515 \mathrm{~cm}^{-1}$ in the $\mathrm{n}=2$ complex, and that

8 this shift decreased with increasing cluster size, to 1583 for $n=3$ and 1630 for $n=4$, as the binding energy

9 per ligand was reduced. ${ }^{60,93}$ Thus based on this comparison of carbonyl stretching data, one would

10 expect the binding of the ACO ligand in the $\left[\mathrm{UO}_{2} \mathrm{OH}(\mathrm{ACO})\right]^{+}$complex to be comparable to binding in

11 the $\left[\mathrm{UO}_{2}(\mathrm{ACO})_{4}\right]^{2+}$ complex. Interestingly, addition of a second and third ACO ligand to

$12\left[\mathrm{UO}_{2} \mathrm{OH}(\mathrm{ACO})\right]^{+}$produced red-shifts consistent with the prior experiments. Photo-fragmentation of

$13\left[\mathrm{UO}_{2} \mathrm{OH}(\mathrm{ACO})_{2}\right]^{+}$and $\left[\mathrm{UO}_{2} \mathrm{OH}(\mathrm{ACO})_{3}\right]^{+}$both resulted in the loss of an $\mathrm{ACO}$, with a $v_{3}$ of 961 and 948

$14 \mathrm{~cm}^{-1}$ respectively. Therefore, a red-shift of 11 and $13 \mathrm{~cm}^{-1}$ were observed on going from

$15\left[\mathrm{UO}_{2} \mathrm{OH}(\mathrm{ACO})\right]^{+}\left[\mathrm{UO}_{2} \mathrm{OH}(\mathrm{ACO})_{2}\right]^{+}$to $\left[\mathrm{UO}_{2} \mathrm{OH}(\mathrm{ACO})\right]^{+}$, which agrees well with the magnitude of the

16 red-shifts resulting from ACO addition to the $\left[\mathrm{UO}_{2}(\mathrm{ACO})_{\mathrm{n}}\right]^{2+}$ complexes. ${ }^{60}$ Taken together, these results

17 suggest that it may be the uranyl antisymmetric stretching frequency in the bare $\left[\mathrm{UO}_{2} \mathrm{OH}\right]^{+}$complex that

18 is anomalously shifted, which is certainly possible given the particular susceptibility of this very small

19 system to anharmonicity effects arising from the IRMPD mechanism. These anharmonicity effects are

20 examined in more detail below. 


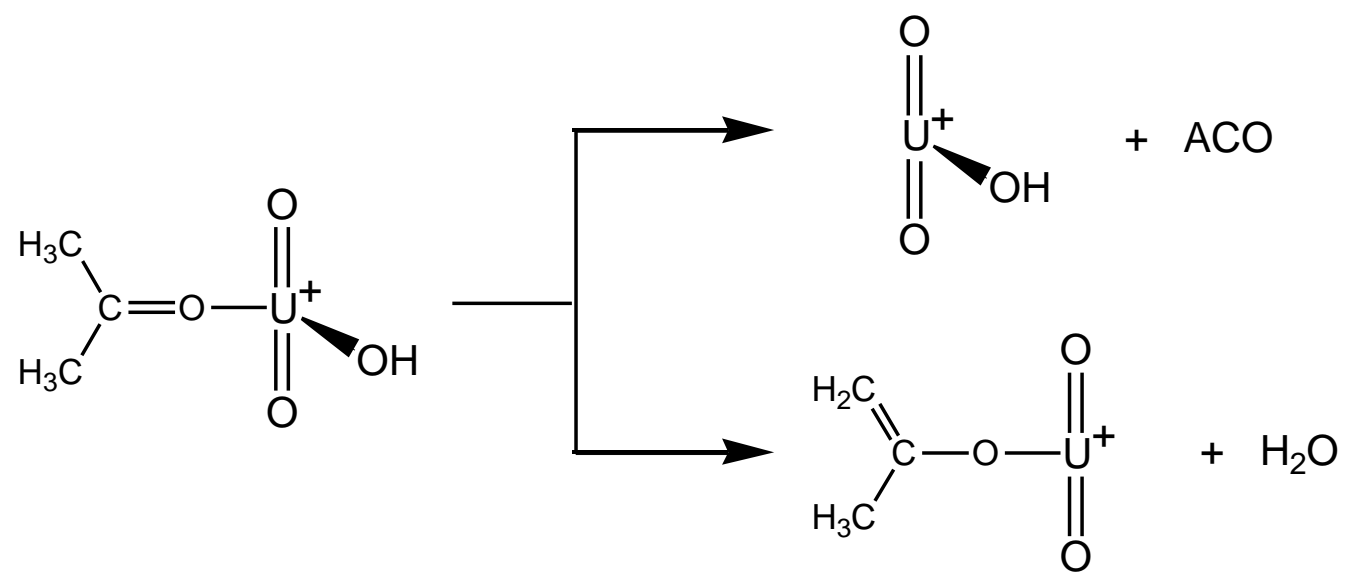

2 Scheme 1. Parallel elimination reactions of isolation and photo-fragmentation of $\left[\mathrm{UO}_{2} \mathrm{OH}(\mathrm{ACO})\right]^{+}$.

3 Table 1. Dissoication energies for IRMPD reactions of $\left[\mathrm{UO}_{2} \mathrm{OH}(\mathrm{ACO})\right]^{+}$calculated using different 4 basis sets.

\begin{tabular}{|c|c|c|}
\hline Reaction / binding energy (kcal/mol) & B3LYP & B3LYP \\
& SVWN & PW91 \\
& Stuttgart RSC & ZORA \\
& TZVP & TZ2P \\
& NWChem & (ADF) \\
\hline$\left[\mathrm{UO}_{2} \mathrm{OH}(\mathrm{ACO})\right]^{+} \rightarrow\left[\mathrm{UO}_{2} \mathrm{OH}\right]^{+}+\mathrm{ACO}$ & 48.3 & 41.4 \\
\hline$\left[\mathrm{UO}_{2} \mathrm{OH}(\mathrm{ACO})\right]^{+} \rightarrow\left[\mathrm{UO}_{2}\left(\mathrm{OC}_{3} \mathrm{H}_{5}\right)\right]^{+}+\mathrm{H}_{2} \mathrm{O}$ & & 41.4 \\
\hline
\end{tabular}

5

6 Isolation of the $\left[\mathrm{UO}_{2} \mathrm{OH}(\mathrm{ACN})\right]^{+}$complex followed by photo-fragmentation produced elimination of 7 ACN. The antisymmetric $\mathrm{UO}_{2}$ stretch was measured at $972 \mathrm{~cm}^{-1}$, nearly identical to that for $8 \quad\left[\mathrm{UO}_{2} \mathrm{OH}(\mathrm{ACO})\right]^{+}$and to $\left[\mathrm{UO}_{2} \mathrm{OH}\right]^{+}$. The hydroxide complex with ammonia $\left[\mathrm{UO}_{2} \mathrm{OH}\left(\mathrm{NH}_{3}\right)\right]^{+}$underwent 9 photo-fragmentation solely by loss of $\mathrm{NH}_{3}$, with a $v_{3}$ value at $976 \mathrm{~cm}^{-1}$, which is slightly blue shifted 10 compared to the unmodified uranyl hydroxide. The final hydroxide complex examined was $11\left[\mathrm{UO}_{2} \mathrm{OH}\left(\mathrm{H}_{2} \mathrm{O}\right)\right]^{+}$, which eliminated $\mathrm{H}_{2} \mathrm{O}$ upon irradiation that maximized at $983 \mathrm{~cm}^{-1}$, which was $1212 \mathrm{~cm}^{-1}$ higher than the $\left[\mathrm{UO}_{2} \mathrm{OH}\right]^{+}$value. 
1 The trend for the uranyl $v_{3}$ frequencies for the $\left[\mathrm{UO}_{2} \mathrm{OH}(\mathrm{S})\right]^{+}$complexes were internally self-

2 consistent, i.e., they decreased in the order $\mathrm{H}_{2} \mathrm{O}>\mathrm{NH}_{3}>\mathrm{ACN} \sim \mathrm{ACO}>(\mathrm{ACO})_{2}$. These frequency

3 values are inversely correlated with the calculated coordination energies of different $\mathrm{S}$ molecules, ${ }^{40}$ and

4 are in accord with comparisons of ACO and ACN uranyl complexes. ${ }^{60}$ The observed ordering again

5 highlights the remarkably low value measured for unmodified $\left[\mathrm{UO}_{2} \mathrm{OH}\right]^{+}$, which would be expected to

6 be higher than $983 \mathrm{~cm}^{-1}$ (i.e., the value for the complex with the most weakly bound neutral,

$\left.7 \quad\left[\mathrm{UO}_{2} \mathrm{OH}\left(\mathrm{H}_{2} \mathrm{O}\right)\right]^{+}\right)$. Because it does not seem reasonable to expect that the addition of weakly donating

8 species actually strengthens the uranyl $\mathrm{U}=\mathrm{O}$ bonds, we must seek other explanations for the blue shifted

9 bands for the $\mathrm{NH}_{3}$ and $\mathrm{H}_{2} \mathrm{O}$ complexes.

10 One likely contributing factor is vibrational anharmonicity derived from the multiple photon

11 absorption process. Red-shifts in the spectra of the para-aminobenzoic acid ${ }^{58}$ and $\left[\mathrm{CeOH}(\mathrm{ACO})_{3}\right]^{2+}$

12 cations $^{93}$ have been attributed to IRMPD anharmonicity, and the same phenomenon may contribute to

13 the low frequency measured for $\left[\mathrm{UO}_{2} \mathrm{OH}\right]^{+}$. These studies demonstrate that when molecules or

14 complexes attain very high internal energies via the IRMPD process, their vibrational bands exhibit non-

15 negligible red-shifts. This can be particularly dramatic for systems with low densities of states, ${ }^{44}$ such as

16 the $\left[\mathrm{UO}_{2} \mathrm{OH}\right]^{+}$complex studied here, which only has 9 vibrational modes. The energy required to

17 dissociate $\left[\mathrm{UO}_{2} \mathrm{OH}\right]^{+}$to $\left[\mathrm{UO}_{2}\right]^{+}$and a hydroxyl radical was evaluated computationally, and both the

18 Stuttgart RSC ECP and the ADF TZ2P basis sets, which have some similarity, produced high values

19 (Table 2). However, a lower value was generated using the LANL/aug-cc-pvdz basis set, which may

20 reflect that difficulty is encountered in dealing with $\left[\mathrm{UO}_{2}\right]^{+}$species using the LANL/aug-cc-pvdz basis

21 set, which is fairly small, without any diffuse functions. This could conceivably create an unbalanced

22 description of uranium, leading to a low calculated dissociation energies. Therefore, we conclude that

23 the calculations in general predict high dissociation energies, which is consistent with the fact that

24 hydroxide had the highest coordination energy of any ligand in the extensive compilation calculated by

25 Marsden and coworkers. ${ }^{40}$ These considerations support the attribution of the anomalously low 
$1 \quad\left[\mathrm{UO}_{2} \mathrm{OH}\right]^{+} v_{3}$ value to anharmonicity effects. The B3LYP calculations using the Stuttgart RSC/TZVP

2 basis was also performed starting from a triplet excited state, and it was found to require $43.8 \mathrm{kcal} \mathrm{mol}^{-1}$.

3 This value, when added to the promotion energy (see below) yields a value of nearly $90 \mathrm{kcal} \mathrm{mol}^{-1}$.

4 Table 2. Dissociation energies calculated for IRMPD of $\left[\mathrm{UO}_{2} \mathrm{OH}\right]^{+}$.

\begin{tabular}{|l|c|c|}
\hline Reaction / binding energy $(\mathrm{kcal} / \mathrm{mol})$ & $\begin{array}{c}\text { B3LYP } \\
\text { SVWN } \\
\text { Stuttgart RSC } \\
\text { TZVP } \\
\text { (NWChem) }\end{array}$ & $\begin{array}{c}\text { B3LYP } \\
\text { PW91 } \\
\text { ZORA } \\
\text { TZ2P } \\
\text { (ADF) }\end{array}$ \\
\hline$\left[\mathrm{UO}_{2} \mathrm{OH}\right]^{+} \rightarrow\left[\mathrm{UO}_{2}{ }^{+}\right]+\mathrm{OH}$ & & 96.0 \\
dissociation via a singlet ground state & & \\
\hline$\left[\mathrm{UO}_{2} \mathrm{OH}\right]^{+} \rightarrow\left[\mathrm{UO}_{2}{ }^{+}\right]+\mathrm{OH}$ & & \\
dissociation via a triplet excited state & & \\
& & \\
\hline
\end{tabular}

5

6 In contrast to the small $\left[\mathrm{UO}_{2} \mathrm{OH}\right]^{+}$molecule, more complex systems containing a neutral ligand tend 7 to have reduced dissociation energies and a significantly higher vibrational density of states. For example, water binds to the $\left[\mathrm{UO}_{2} \mathrm{OH}\right]^{+}$complex by only $30 \mathrm{kcal} / \mathrm{mol}$, while doubling the number of

9 vibrational modes, three of which are low-frequency intermolecular modes, that may contribute 10 disproportionately to the vibrational density of states. This may explain why the $v_{3}$ frequencies of the $11\left[\mathrm{UO}_{2} \mathrm{OH}(\mathrm{S})\right]^{+}$complexes are not apparently affected by anharmonicity, compared to the bare $\left[\mathrm{UO}_{2} \mathrm{OH}\right]^{+}$ 12 which is strongly shifted by anharmonicity induced by the IRMPD process. A $v_{3}$ value unshifted by 13 anharmonicity would be expected to be $\sim 990 \mathrm{~cm}^{-1}$ for $\left[\mathrm{UO}_{2} \mathrm{OH}\right]^{+}$to be consistent with the trend in the $v_{3}$ 14 bands of the $\left[\mathrm{UO}_{2} \mathrm{OH}(\mathrm{S})\right]^{+}$complexes measured here.

15 Correlation corrected vibrational SCF (cc-VSCF) calculations can provide an estimate of whether or 16 not differential red-shifting would be expected in comparing $\left[\mathrm{UO}_{2} \mathrm{OH}\right]^{+}$and $\left[\mathrm{UO}_{2} \mathrm{OH}(\mathrm{S})\right]^{+}$complexes. 
1 cc-VSCF estimates the effect of anharmonicity by including coupling between the lower vibrational

2 modes calculated in the harmonic approximation. Factoring in an influence by anharmonicity the

3 calculated $v_{3}$ value for $\left[\mathrm{UO}_{2} \mathrm{OH}\right]^{+}$decreased by $10 \mathrm{~cm}^{-1}$, which would account for part of the expected

4 red shift for the hydroxide based on the IRMPD data. However, the shift calculated for $\left[\mathrm{UO}_{2} \mathrm{OH}\left(\mathrm{H}_{2} \mathrm{O}\right)\right]^{+}$

5 was very nearly the same at $8 \mathrm{~cm}^{-1}$, since there are other factors that are expected to mitigate the effects

6 of anharmonicity in the latter system, the differential anharmonic shift calculated for $\left[\mathrm{UO}_{2} \mathrm{OH}\right]^{+}$and

$7 \quad\left[\mathrm{UO}_{2} \mathrm{OH}\left(\mathrm{H}_{2} \mathrm{O}\right)\right]^{+}$. It should be noted that the cc-VSCF calculations only consider coupling of the lowest

$8 \sim 10$ vibrational levels, whereas coupling and population of the higher excitation levels would certainly

9 be expected to contribute at the high excitation energies achieved in the IRMPD experiments.

10 Participation of an electronically excited state $\left[\mathrm{UO}_{2} \mathrm{OH}\right]^{+}$may also contribute to the apparently low $v_{3}$

11 frequency. The energy calculated for promotion of an electron into the lowest excited triplet state

12 calculated using both B3LYP/LANL2dz-aug-cc-pVDZ and PW91/unrestricted/scalar was $\sim 45 \mathrm{kcal} / \mathrm{mol}$,

13 which was less than that calculated to dissociate $\left[\mathrm{UO}_{2} \mathrm{OH}\right]^{+}$(except for the LANL basis set). If

14 vibrational-to-electronic transitions are occurring in the multiple photon experiments, then a lowered

15 frequency would be expected for the electronically excited molecule. ${ }^{94}$ The $v_{3}$ value calculated for

$16\left[\mathrm{UO}_{2} \mathrm{OH}\right]^{+}$in its lowest excited state was quite a bit lower, at $908 \mathrm{~cm}^{-1}$, however the hydroxide profile is

17 broadened, which may be the result of overlap of absorptions of ground state and excited state

18 molecules. It should also be noted that this triplet state may be directly related to the observed

19 dissociation pathway, suggesting that the molecule can be considered to be a complex of reduced uranyl

$20\left[\mathrm{UO}_{2}\right]^{+}$and neutral hydroxyl radical.

21 IRMPD of Uranyl-Acetate Complexes $\left[\mathrm{UO}_{2} \mathrm{OAc}^{+}\right.$. ESI produced a relatively abundant ion at $\mathrm{m} / \mathrm{z} 329$

22 which was attributed to uranyl acetate $\left[\mathrm{UO}_{2} \mathrm{OAc}\right]^{+}$, that was formed from residual acetic acid that had

23 been used to enhance the protonated ion formation from peptide and protein solutions in previous

24 experiments at FELIX. Because acetate is a stronger conjugate base, it replaces nitrate in the ion

25 accumulation chamber prior to injection into the FT-ICR-MS. The composition was confirmed by 
accurate mass measurement and the photo-fragmentation pathway observed in the IRMPD experiment, in which a neutral loss of 42 mass units (presumably as ketene) furnished $\left[\mathrm{UO}_{2} \mathrm{OH}\right]^{+}$as the product ion.

3 For IRMPD of $\left[\mathrm{UO}_{2} \mathrm{OAc}\right]^{+}$the maximum for the antisymmetric uranyl stretch was $995 \mathrm{~cm}^{-1}$ (Figure 2),

4 higher than any of the hydroxide complexes measured. This is consistent with the fact that acetate is a

5 weaker gas-phase base ${ }^{95}$ than either hydroxide or methoxide (vide infra), and consequently is also likely

6 to be a weaker uranophile. Despite the presumed lower basicity, the antisymmetric uranyl stretching

7 frequency for $\left[\mathrm{UO}_{2} \mathrm{OAc}\right]^{+}$appeared at a lower value than nearly all of the uranyl dication complexes

8 ligated with multiple neutral donor ligands reported earlier. ${ }^{60}$ In solution, acetate complexes have been

9 the subject of several infrared studies, and the most appropriate value for the antisymmetric stretch to

10 use in a comparison is $954 \mathrm{~cm}^{-1}$, which was measured by Quiles ${ }^{17}$ for $\left[\mathrm{UO}_{2} \mathrm{OAc}\right]^{+}$. This value is

11 significantly lower than the IRMPD measurement, which reflects the attachment of additional solvent

12 ligands to the $\left[\mathrm{UO}_{2} \mathrm{OAc}\right]^{+}$metal center. Other studies have produced values that ranged as low as 919

$13 \mathrm{~cm}^{-1},{ }^{18,23}$ but these measurements probably contain contributions from species that contain more than

14 one acetate ligand, and the possibility of variable acetate coordination. ${ }^{17}$ Recently, LDA was used by de

15 Jong and coworkers to calculate uranyl $v_{3}$ value for $\left[\mathrm{UO}_{2} \mathrm{OAc}\right]^{+}$at $1025 \mathrm{~cm}^{-1} .{ }^{96}$ A careful examination

16 of the carbonyl stretching frequencies could provide insight into this, and will be investigated in further

17 experimental campaigns.

18 Also observed in the ESI spectrum were low abundance ions at $\mathrm{m} / \mathrm{z} 346$ and 347 that corresponded to 19 ammonia and water complexes (respectively), having compositions $\left[\mathrm{UO}_{2} \mathrm{OAc}\left(\mathrm{NH}_{3}\right)\right]^{+}$and $20\left[\mathrm{UO}_{2} \mathrm{OAc}\left(\mathrm{H}_{2} \mathrm{O}\right)\right]^{+}$. Photo-fragmentation of these complexes involved elimination of either $\mathrm{NH}_{3}$ or $\mathrm{H}_{2} \mathrm{O}$, 21 producing $\left[\mathrm{UO}_{2} \mathrm{OAc}\right]^{+}$in each case. Consistent with prior studies of donors, the antisymmetric $\mathrm{UO}_{2}$ 22 stretching frequency was red-shifted for both $\mathrm{H}_{2} \mathrm{O}$ and $\mathrm{NH}_{3}$ complexes relative to $\left[\mathrm{UO}_{2} \mathrm{OAc}\right]^{+}$, although 23 the magnitude of the shifts were small: the value for the $\mathrm{H}_{2} \mathrm{O}$ complex at $993 \mathrm{~cm}^{-1}$ was lower by $2 \mathrm{~cm}^{-1}$, 24 while a shift $7 \mathrm{~cm}^{-1}$ to $988 \mathrm{~cm}^{-1}$ was observed for the $\mathrm{NH}_{3}$ complex. The trend in the measured 25 frequencies indicate that both $\mathrm{H}_{2} \mathrm{O}$ and $\mathrm{NH}_{3}$ are donating electron density, and that $\mathrm{NH}_{3}$ is a stronger 
1 uranophile than is $\mathrm{H}_{2} \mathrm{O}$, consistent with Marsden's prior DFT results, ${ }^{40}$ the relative order of proton

2 affinities, ${ }^{95}$ and bonding to other metal cations. ${ }^{97}$ The fact that the frequency of the unmodified acetate is

3 very close to that of both ligand complexes suggests that the frequency for the $\left[\mathrm{UO}_{2} \mathrm{OAc}^{+}\right.$complex may

4 also be red-shifted as a result of anharmonicity or perhaps other factors. However the effect is less

5 pronounced than in the case of the hydroxide complex, as indicated by the fact that the $v_{3}$ of the

6 unmodified $\left[\mathrm{UO}_{2} \mathrm{OAc}\right]^{+}$complex is not lower than the values of the $\mathrm{H}_{2} \mathrm{O}$ and $\mathrm{NH}_{3}$ adducts. Compared to

7 the hydroxide complex, a smaller anharmonic red shift for OAc is consistent with a higher density of 8 states, ${ }^{44}$ and with a lower energy requirement for fragmentation of the acetate complex, which involves 9 rearrangement rather than direct bond-cleavage and elimination of a radical.

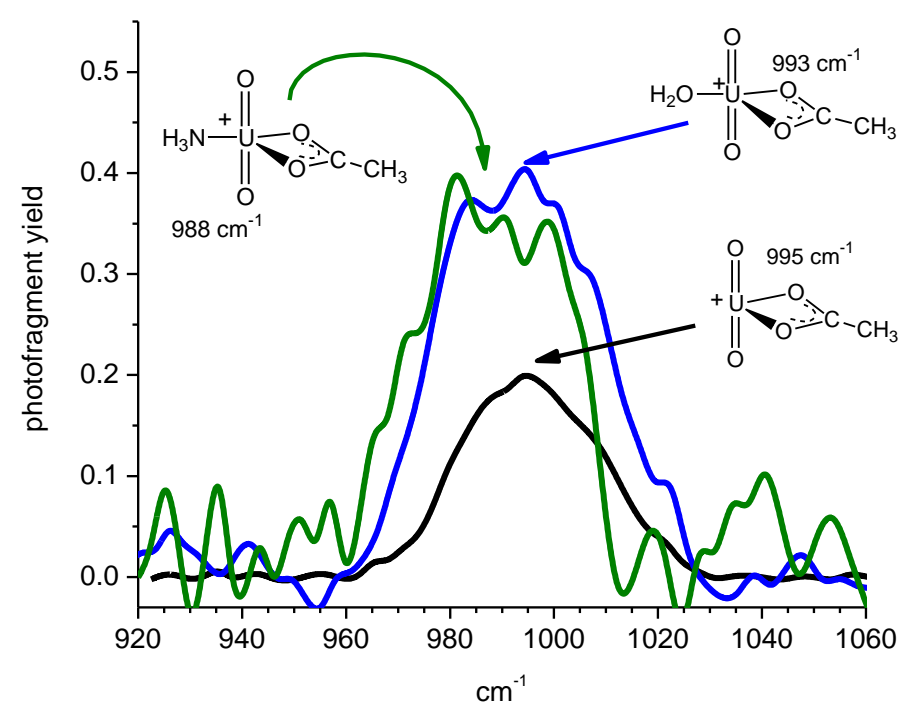

11 Figure 2. Infrared multiple photon dissociation spectra of the antisymmetric $\mathrm{O}=\mathrm{U}=\mathrm{O}$ stretching region 12 for $\left[\mathrm{UO}_{2} \mathrm{OAc}\right]^{+}$and ligand complexes containing a single $\mathrm{NH}_{3}$ and $\mathrm{H}_{2} \mathrm{O}$.

13 IRMPD of Uranyl-Methoxide Complexes [UO $\left.{ }_{2} \underline{O C H}_{3}\right]^{+}$. The accurate mass measurement of the ion at $14 \mathrm{~m} / \mathrm{z} 301$ confirmed the composition of uranyl methoxide, which was formed by reaction of uranyl 15 species with methanol that was present in the ESI solution. Photo-fragmentation of $\left[\mathrm{UO}_{2} \mathrm{OCH}_{3}\right]^{+}$ 16 produced four different product ions corresponding to the elimination of the $\mathrm{OCH}_{3}$ and $\mathrm{H}$ radicals, $\mathrm{H}_{2}$, 17 and $\mathrm{H}_{2} \mathrm{CO}$ (Scheme 2). 


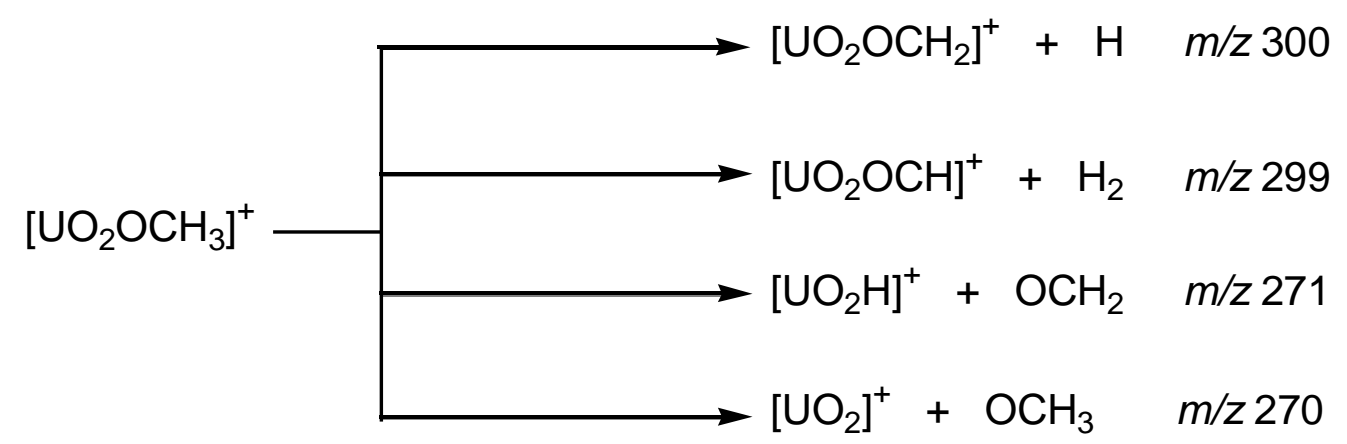

2 Scheme 2: Photo-fragmentation of $\left[\mathrm{UO}_{2} \mathrm{OCH}_{3}\right]^{+}$produced four different product ions corresponding to

3 the elimination of the $\mathrm{OCH}_{3}$ and $\mathrm{H}$ radicals, $\mathrm{H}_{2}$, and $\mathrm{H}_{2} \mathrm{CO}$.

4 The IRMPD spectrum of the methoxide complex contained two bands, with maxima at $975 \mathrm{~cm}^{-1}$ and $5887 \mathrm{~cm}^{-1}$ (Figure 3, black trace). DFT calculations (B3LYP/SDD-3-21G*) indicated that the higher 6 frequency corresponded to overlapped antisymmetric uranyl $v_{3}$ and C-O stretching bands, and the lower

7 frequency to the symmetric uranyl $v_{1}$ band normally observed in the Raman spectrum. ${ }^{7,12,15,22,29}$ The 8 appearance of the symmetric stretch indicates a lowered symmetry in the complex, resulting from strong 9 binding of the methoxide that perturbs the linearity of the uranyl functional group. This was supported 10 by the lowest energy structures and bond angles produced by B3LYP calculations (vide infra).

11 Striking differences were observed when the IR spectra produced using the different photo12 dissociation channels were compared. The spectrum generated by monitoring the loss of the $\mathrm{OCH}_{3}$ 13 radical contained a single sharply defined peak with a maximum at $967 \mathrm{~cm}^{-1}$, a frequency slightly lower 14 than that measured for the uranyl antisymmetric stretch for the unmodified hydroxide complex, and 15 consistent with the fact that methoxide is a stronger base than is hydroxide. The peak centered at 967 $16 \mathrm{~cm}^{-1}$ was not observed in the spectra generated by the other three fragmentation channels, either because 17 it is not occurring in these channels, or because it was overlapped with the O-C stretch (see below). If 18 the latter is true, then it suggests that the $v_{3}$ frequency in the spectrum of the $\mathrm{OCH}_{3}$ loss channel is red 19 shifted by about $20 \mathrm{~cm}^{-1}$ due to the higher energetic requirements for that channel; shifts of this 20 magnitude have been observed previously. ${ }^{58}$ 


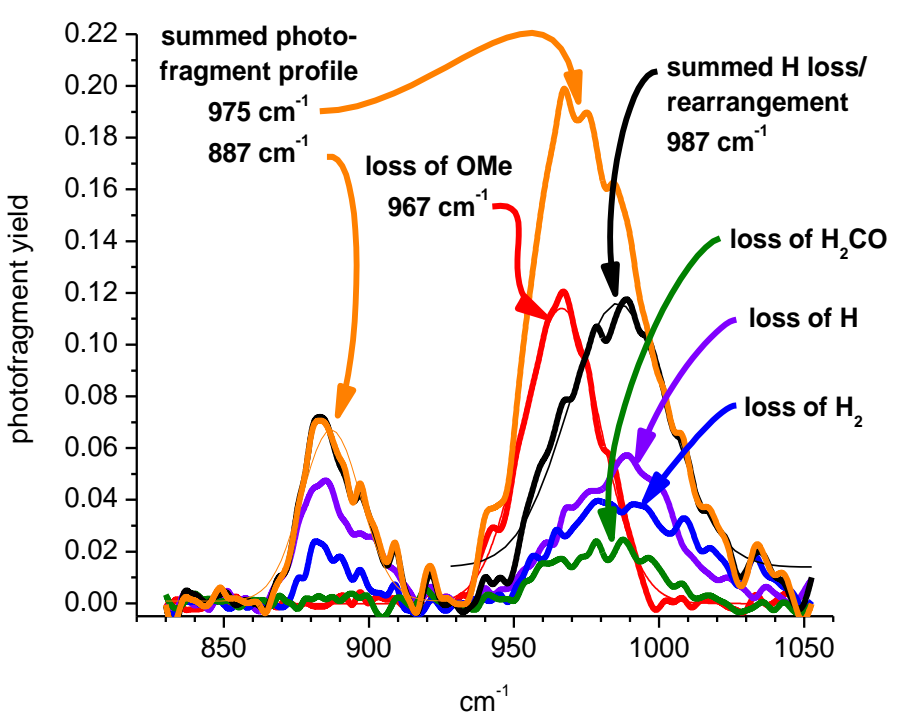

2 Figure 3. Infrared multiple photon dissociation spectra of the symmetric and antisymmetric $\mathrm{O}=\mathrm{U}=\mathrm{O} v_{3}$

3 stretching region for $\left[\mathrm{UO}_{2} \mathrm{OCH}_{3}\right]^{+}$. The black trace represents the spectrum generated by the summed

4 photofragment abundance; red the $\mathrm{OCH}_{3}$ radical elimination, violet the $\mathrm{H}$ radical elimination; blue the

$5 \mathrm{H}_{2}$ elimination; green the $\mathrm{H}_{2} \mathrm{CO}$ elimination, and orange the sum of the $\mathrm{H}$ loss/rearrangement related

6 channels.

7 The IR spectra generated from the photo-dissociation channels corresponding to either the loss of $\mathrm{H}$ or

$8 \mathrm{H}_{2}$ bore strong similarities to one another in that they contained a peak with a maximum at $987 \mathrm{~cm}^{-1}$ and

9 second peak at about $887 \mathrm{~cm}^{-1}$. The higher frequency peak probably contains components from

10 unresolved uranyl asymmetric stretch and C-O stretching, while the lower frequency peak corresponds

11 to the symmetric $\mathrm{UO}_{2}$ stretch. The IR spectrum generated by the $\mathrm{H}_{2} \mathrm{CO}$ elimination was similar to the $\mathrm{H}$ -

12 loss spectra, but lacked the band for the symmetric stretch. The appearance of very dissimilar IR spectra

13 in the different photo-dissociation channels was remarkable, because IRMPD spectra generated from

14 competing mass channels are normally identical or are very similar, with the fragmentation channels

15 having the higher energetic requirements being modestly red-shifted as a result of anharmonicity that

16 results from population of higher vibrational levels when multiple photons are serially absorbed. ${ }^{58,93}$

17 Fast intramolecular vibrational redistribution randomizes the deposited energy regardless of the 
1 frequency of initial deposition, and thus the competing fragmentation channels display similar if not

2 identical IR spectra. ${ }^{56}$

3 A hypothetical interpretation of these observations is that the order of reaction endothermicities for the

4 four reactions is $-\mathrm{H}_{2} \sim-\mathrm{H}<-\mathrm{OCH}_{2}<-\mathrm{OCH}_{3}$. In the spectra generated by losses of $\mathrm{H}$ and $\mathrm{H}_{2}$ peaks are

5 seen in all three absorption modes, symmetric uranyl, asymmetric uranyl and C-O (assuming that the

6 asymmetric uranyl and C-O are overlapping). The symmetric uranyl and C-O are weakly absorbing

7 modes and hence are only seen in those eliminations having low energy requirements. The spectrum

8 generated by loss of $\mathrm{OCH}_{2}$ contains the asymmetric uranyl and perhaps the $\mathrm{C}-\mathrm{O}$, but energetic

9 requirement for this channel is too high to enable observation of the symmetric uranyl stretch. The

10 higher energetic requirements are probably related to the fact that the $\left[\mathrm{UO}_{2} \mathrm{H}\right]^{+}$product ion has to be

11 reduced, forming either a U(IV) species or a uranyl hydride. Finally, the spectrum generated by loss of

$12 \mathrm{OCH}_{3}$ contains only the antisymmetric uranyl peak, because the energetics for this reaction are higher,

13 which means that it can only be accessed via the high intensity $v_{3}$ uranyl absorption. This peak is

14 substantially red-shifted as a consequence of the large number of photons that must be deposited in

15 order for the reaction to occur. Further, the fast kinetics of the $\mathrm{OCH}_{3}$ radical loss reduces observation of 16 the slower, lower energy losses.

17 Enthalpy changes for the calculated for the different fragmentation channels display modest agreement

18 with this hypothesis. B3LYP calculations using different parameterization and basis sets (Table 3)

19 showed that elimination of $\mathrm{H}_{2}$ was the lowest, followed by loss of $\mathrm{H}$ radical. Enthalpy requirements for

20 the loss of $\mathrm{H}_{2} \mathrm{CO}$ and reductive elimination of the methoxy radical were higher, and the order of these

21 two varied depending on the basis sets employed. The B3LYP calculations identified two possible

22 outcomes for the elimination of $\mathrm{H}_{2} \mathrm{CO}$ : formation of a $\mathrm{U}(\mathrm{IV})$ oxyhydroxide [UOOH] $]^{+}$, and a U(VI)

23 uranyl hydride $\left[\mathrm{UO}_{2} \mathrm{H}\right]^{+}$, with the U(IV) species appearing to be somewhat disfavored energetically.

24 However the significant energetic variations seen in comparisons of the different approaches do not

25 allow us to state the energetic order of the elimination reactions, and thus computational support is 
1 somewhat equivocal for the hypothetical explanation for the differences seen in the spectra from the four

2 elimination channels.

3 Table 3. Calculated enthalpies for the dissociation reactions of $\left[\mathrm{UO}_{2} \mathrm{OCH}_{3}\right]^{+}$(Scheme 2). Values are in $4 \quad \mathrm{kcal} \mathrm{mol}^{-1}$.

\begin{tabular}{|c|c|c|c|c|}
\hline Reaction $\backslash$ binding energy ( $\mathrm{kcal} / \mathrm{mol}$ ) & $\begin{array}{c}? ? ? ? ? ? \\
\text { SVWN } \\
\text { DNP } \\
\text { DNP } \\
\text { (DMOL) }\end{array}$ & $\begin{array}{c}\text { B3LYP } \\
\text { B3LYP } \\
\text { SDD } \\
\text { SDD } \\
\text { (Gaussian) }\end{array}$ & $\begin{array}{c}\text { B3LYP } \\
\text { SVWN } \\
\text { Stuttgart } \\
\text { RSC } \\
\text { TZVP } \\
\text { (NWChem) }\end{array}$ & $\begin{array}{l}\text { B3LYP } \\
\text { PW91 } \\
\text { ZORA } \\
\text { TZ2P } \\
\text { (ADF)* }\end{array}$ \\
\hline$\left[\mathrm{UO}_{2} \mathrm{OCH}_{3}\right]+\rightarrow \mathrm{H}_{2}+\left[\mathrm{UO}_{2}(\mathrm{OCH})\right]^{+}$ & & 52.8 & 52.7 & 52.3 \\
\hline$\left[\mathrm{UO}_{2} \mathrm{OCH}_{3}\right]+\rightarrow \mathrm{H} \quad+\left[\mathrm{UO}_{2}\left(\mathrm{OCH}_{2}\right)\right]^{+}$ & & 67.3 & 73.7 & 78.3 \\
\hline$\left[\mathrm{UO}_{2} \mathrm{OCH}_{3}\right]+\rightarrow \mathrm{OCH}_{3}+\left[\mathrm{UO}_{2}\right]^{+}$ & & 68.4 & 69.8 & 100.1 \\
\hline $\begin{array}{r}{\left[\mathrm{UO}_{2} \mathrm{OCH}_{3}\right]+\rightarrow \mathrm{OCH}_{2}+\left[\mathrm{UO}_{2}(\mathrm{H})\right]^{+}} \\
(\mathrm{H} \text { equatorial })\end{array}$ & & 59.0 & 80.7 & -- \\
\hline $\begin{array}{r}{\left[\mathrm{UO}_{2}-\mathrm{OCH}_{3}\right]+\rightarrow \mathrm{OCH}_{2}+[\mathrm{UOOH}]^{+}} \\
\text {(H linear) }\end{array}$ & & 79.9 & 85.2 & 85.6 \\
\hline
\end{tabular}

* ZORA numbers include spin-orbit interaction.

6 An alternative explanation would be the existence of two or more isomers of $\left[\mathrm{UO}_{2} \mathrm{OCH}_{3}\right]^{+}$, however

7 DFT calculations did not support the existence of energetically competitive isomers, although 8 rearrangement may be occurring during the IRMPD process. An alternative structure that was

9 considered contained an $\mathrm{H}$ atom bound to uranium, with formaldehyde equatorially coordinated: for 10 such a structure an absoption corresponding to carbonyl group should be observed, but a survey of the 11 1500-1700 $\mathrm{cm}^{-1}$ wavelength region did not show an additional peak. Thus a structure involving a bound

12 formaldehyde ligand is unlikely, as our prior studies ${ }^{60,93}$ showed that the $\mathrm{C}=\mathrm{O}$ stretch can be readily 13 detected in complexes with carbonyl-containing ligands.

14 Involvement of an excited state for the uranyl methoxide can also be argued, which would be expected 15 to have energetic requirements similar to the $45 \mathrm{kcal} / \mathrm{mol}$ required for the hydroxide complex.

16 Intuitively, this is an attractive explanation because a higher spin species would be expected to have a 17 higher propensity for rearrangement and elimination of $\mathrm{H}$ and $\mathrm{OCH}_{3}$ radicals. When the energetic 
1 requirement for conversion to a triplet excited state was calculated, it was found to be $45 \mathrm{kcal} \mathrm{mol}^{-1}$, in a

2 range that would be accessible during the IRMPD photofragmentation. However, as in the two

3 previously offered rationalizations, this too remains speculative at the present time, and hence an

4 unequivocal identification of the origin of the differences in the spectra of the different mass channels is

5 still elusive.

6 The assignment of the higher frequency to a C-O stretch drew support from the spectra acquired for

7 the $\left[\mathrm{UO}_{2} \mathrm{OCH}_{3}\left(\mathrm{H}_{2} \mathrm{O}\right)\right]^{+}$and $\left[\mathrm{UO}_{2} \mathrm{OCH}_{3}\left(\mathrm{NH}_{3}\right)\right]^{+}$adducts (Figure 4). The three peaks in the spectra of

8 these complexes had frequencies consistent with the spectra of unmodified $\left[\mathrm{UO}_{2} \mathrm{OCH}_{3}\right]^{+}$. In the adduct

9 ions, photo-fragmentation of the methoxide ligand did not occur; instead, only the energetically favored

10 losses of $\mathrm{H}_{2} \mathrm{O}$ or $\mathrm{NH}_{3}$ were observed.

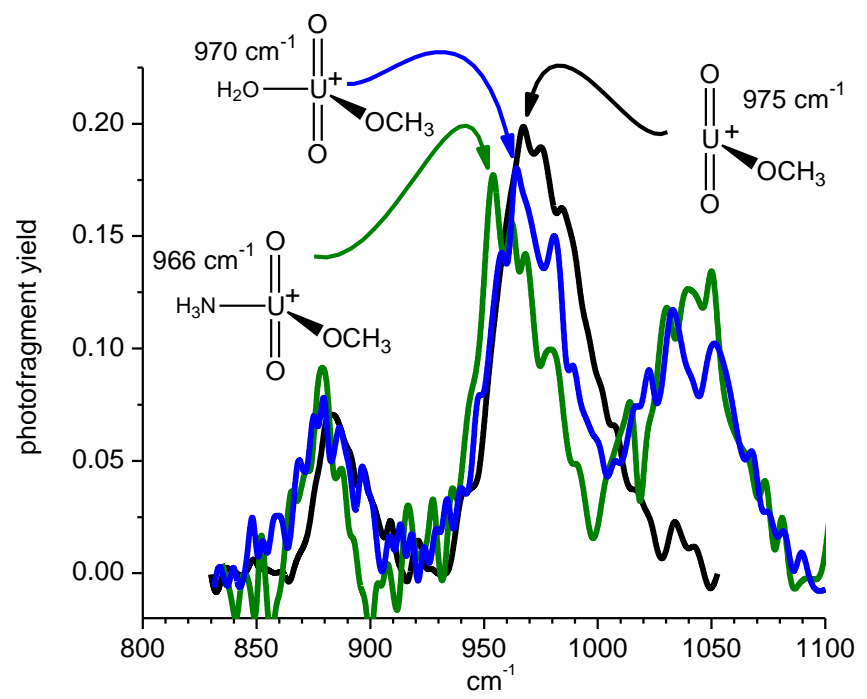

12 Figure 4. Infrared multiple photon dissociation spectra of the antisymmetric $\mathrm{O}=\mathrm{U}=\mathrm{O}$ stretching region 13 for $\left[\mathrm{UO}_{2} \mathrm{OCH}_{3}\right]^{+}$(black trace, sum of all photo-fragment channels), $\left[\mathrm{UO}_{2} \mathrm{OCH}_{3}\left(\mathrm{H}_{2} \mathrm{O}\right)\right]^{+}$(blue trace, 14 scaled by 0.55 ) and $\left[\mathrm{UO}_{2} \mathrm{OCH}_{3}\left(\mathrm{NH}_{3}\right)\right]^{+}$(green trace scaled by 0.6 ). The photofragment yield for the $\mathrm{H}_{2} \mathrm{O}$ 15 and $\mathrm{NH}_{3}$ complexes was higher than for the unmodified methoxide complex, and scaling was performed 16 to facilitate comparison. 
The frequencies measured for the antisymmetric $\mathrm{UO}_{2}$ stretch for the $\mathrm{H}_{2} \mathrm{O}$ and $\mathrm{NH}_{3}$ complexes were modestly red-shifted compared to the maximum value for the summed photo-fragment channels of the unmodified $\left[\mathrm{UO}_{2} \mathrm{OCH}_{3}\right]^{+}$, and the trend observed is consistent with what would be expected for addition of a second weak donor ligand $\left(\mathrm{H}_{2} \mathrm{O}\right)$, and then substitution of a slightly more basic ligand $\mathrm{NH}_{3}$ for $\mathrm{H}_{2} \mathrm{O}$. Similarly, the frequencies measured for the symmetric stretch were very similar for all three complexes: the $v_{1}$ value for the unmodified $\left[\mathrm{UO}_{2} \mathrm{OCH}_{3}\right]^{+}$was measured at $887 \mathrm{~cm}^{-1}$, and the peak position is only very modestly shifted to $880 \mathrm{~cm}^{-1}$ when $\mathrm{H}_{2} \mathrm{O}$ is attached, and to $879 \mathrm{~cm}^{-1}$ for $\mathrm{NH}_{3}$. These values are about $20 \mathrm{~cm}^{-1}$ higher than that measured for solvated $\left[\mathrm{UO}_{2} \mathrm{OAc}\right]^{+}$using Raman spectroscopy. ${ }^{12}$ As in the case of the hydroxide complexes, the uranyl stretching frequencies of the methoxide complexes were not significantly red shifted by addition of a neutral donor ligand. This suggests that in the unmodified methoxide complex $\left[\mathrm{UO}_{2} \mathrm{OCH}_{3}\right]^{+}$, the uranyl frequency may be shifted to a lower value as a result of anharmonicity, in a fashion similar to that suspected to be occurring in the hydroxide complexes. As noted, this would be facilitated by high energetic requirements for the elimination reaction in the unmodified $\left[\mathrm{UO}_{2} \mathrm{OCH}_{3}\right]^{+}$which was indicated by calculations, and was comparable to the value calculated for the hydroxide. The high value is consistent with the idea that elimination of the $\mathrm{OCH}_{3}$ radical would be most susceptible to red-shifting resulting from absorption of multiple photons during the IRMPD process.

While addition of a second donor ligand does not cause large changes in the uranyl stretching frequencies, ${ }^{43,96}$ it appears to strengthen the C-O bond in the methoxide ligand. This would be expected if the methoxide were modestly repelled by attachment of $\mathrm{H}_{2} \mathrm{O}$ or $\mathrm{NH}_{3}$ to the uranium center. In the spectra for both $\left[\mathrm{UO}_{2} \mathrm{OCH}_{3}\left(\mathrm{H}_{2} \mathrm{O}\right)\right]^{+}$and $\left[\mathrm{UO}_{2} \mathrm{OCH}_{3}\left(\mathrm{NH}_{3}\right)\right]^{+}$, the C-O stretch was observed at ca. 1038 and $1040 \mathrm{~cm}^{-1}$, shifted to higher frequency by $\sim 50 \mathrm{~cm}^{-1}$ compared to unmodified $\left[\mathrm{UO}_{2} \mathrm{OCH}_{3}\right]^{+}$. This trend is directly analogous to what was observed in the IR spectra of discrete uranyl acetone dication complexes: when an additional donor ligand was added, the binding of all equatorial ligands was weakened, and the $\mathrm{C}=\mathrm{O}$ stretching frequency increased, approaching that of free acetone; ${ }^{60}$ in the 
1 present case, it is the $\mathrm{C}-\mathrm{O}$ stretch of methoxide that is increased. Calculations also suggested loosening

2 of the $\mathrm{U}-\mathrm{OCH}_{3}$ bond upon ligation with a neutral donor.

\section{$3 \quad$ Comparisons of Calculated Frequencies}

4 The changes in vibrational frequencies can be understood in part by comparison with frequencies,

5 bond lengths and angles calculated using density functional theory. Because calculations of complexes

6 containing actinide elements are challenging, different combinations of functionals and basis sets were used. These results provided multiple opportunities for comparison with measurements, in particular using the antisymmetric uranyl stretch, which was the salient figure of merit in this study. A comparison

9 of the unscaled uranyl frequencies calculated using B3LYP with different basis sets versus the IRMPD 10 measurements (Figure 5, Table 4) showed that more accurate values were obtained using the SDD basis 11 set for all elements. Calculated values using $3-21 \mathrm{~g} *$ and $6-31+\mathrm{g}(\mathrm{d})$ for $\mathrm{C}, \mathrm{H}, \mathrm{N}$ and $\mathrm{O}$ were $20-30 \mathrm{~cm}^{-1}$ 12 higher than measurements for the solvent complexes, depending on the donor. Values calculated using $136-31+g(d)$ were slightly better than those generated using $3-21 g^{*}$, but differences between the two 14 calculations were small. The data in Figure 5 may be grouped into three categories: anion complexes with no donor, an $\mathrm{O}$-donor $\left(\mathrm{H}_{2} \mathrm{O}\right.$ or acetone $)$, or an $\mathrm{N}$-donor $\left(\mathrm{NH}_{3}\right.$ or acetonitrile). Calculations for the O-donor anion complexes were in best agreement with experiments, being within a few $\mathrm{cm}^{-1}$ for the all17 SDD basis sets, and on the order of $20 \mathrm{~cm}^{-1}$ high for the SDD/3-21g* and SDD/6-31+g(d) basis sets.

18 Calculations for the complexes containing a neutral that coordinates via a $\mathrm{N}$ atom were slightly less 19 accurate, with differences ranging from $5-10 \mathrm{~cm}^{-1}$ for the all-SDD calculation to $\sim 30 \mathrm{~cm}^{-1}$ using the 20 gen basis sets. This suggests that $\mathrm{N}$-donation is slightly more aggressive in the gas phase experiment 21 than predicted by theory. Calculations for the $\left[\mathrm{UO}_{2} \text { (anion) }\right]^{+}$complexes containing no neutral donor 22 displayed the poorest agreement with experiment, being 20 to nearly $60 \mathrm{~cm}^{-1}$ higher than the 23 measurements, depending on the basis set used. The poorer agreement likely reflects the high energetic 24 requirements for photo-fragmentation pathways for these complexes, which is reasonable since they 25 involve elimination of an oxy radical with concomittant reduction of the uranium center. The need to 
1 vibrationally excite the uranyl-anion complexes to a higher level increases the opportunity for the

2 measured $v_{3}$ value to be shifted lower as a result of vibrational anharmonicity, or perhaps by 3 participation of an excited state, as suggested above.

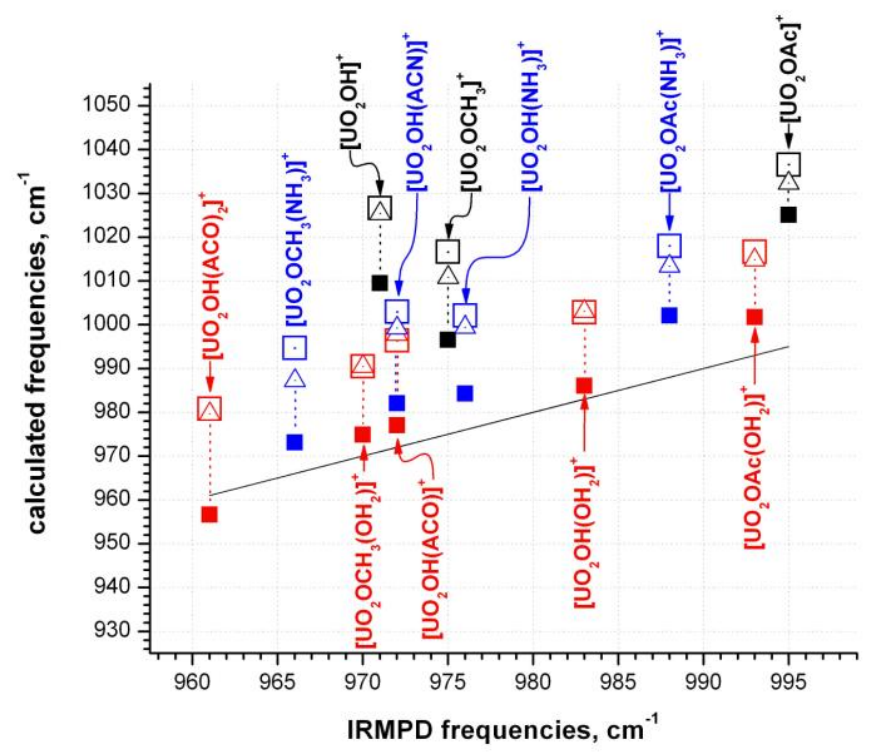

5 Figure 5. Uranyl $v_{3}$ frequencies calculated using B3LYP plotted versus IRMPD measurements. The line 6 represents the experimental data. Filled square data points were generated using the SDD basis set for all 7 elements, values unscaled. Values represented by open squares were generated using SDD for uranium 8 and 3-21g* for $\mathrm{C}, \mathrm{H}, \mathrm{N}$ and $\mathrm{O}$, while values represented by open triangles utilized 6-31g(d) for $\mathrm{C}, \mathrm{H}, \mathrm{N}$ 9 and O. Black points represent $\left[\mathrm{UO}_{2} \text { (anion) }\right]^{+}$complexes with no neutral donor, red represent those with 10 O-donating neutrals, and blue represent those with N-donating neutrals. 
1 Table 4a. Uranyl antisymmetric stretching frequencies $\left(v_{3}\right)$ for complexes $\left[\mathrm{UO}_{2} \mathrm{AS}_{0,1,2}\right]^{+}$. IRMPD values

2 were generated experimentally, and calculated using the B3LYP functional with various basis sets. All 3 values reported are unscaled.

\begin{tabular}{|c|c|c|c|c|c|c|c|}
\hline $\begin{array}{c}\text { A } \\
\text { (anion) }\end{array}$ & $\begin{array}{c}\mathrm{S} \\
\text { (neutral } \\
\text { solvent) }\end{array}$ & $\begin{array}{c}\text { IRMPD } \\
\text { measure- } \\
\text { ments }\end{array}$ & $\begin{array}{l}\text { B3LYP/ } \\
\text { SDD/ } \\
3-21 g^{*}\end{array}$ & $\begin{array}{l}\text { B3LYP/ } \\
\text { Stuttgart } \\
\text { RSC/RLC } \\
\text { (SDD) }\end{array}$ & $\begin{array}{c}\text { B3LYP/ } \\
\text { Stuttgart } \\
\text { RSC/RLC } \\
\text { (SDD)/ } \\
6-31+\mathrm{g}(\mathrm{d})\end{array}$ & $\begin{array}{c}\text { B3LYP/ } \\
\text { Stuttgart } \\
\text { RSC/RLC/ } \\
\text { TZVP }\end{array}$ & $\begin{array}{c}\text { B3LYP/ } \\
\text { LANL2dz/ } \\
\text { aug-cc- } \\
\text { pvdz }\end{array}$ \\
\hline $\mathrm{OH}$ & - & 971 & 1027 & 1009 & 1025 & 1035 & 988 \\
\hline $\mathrm{OH}$ & $\mathrm{H}_{2} \mathrm{O}$ & 983 & 1003 & 986 & 1003 & 1015 & 971 \\
\hline $\mathrm{OH}$ & $\mathrm{NH}_{3}$ & 976 & 1002 & 984 & 999 & 1011 & 964 \\
\hline $\mathrm{OH}$ & $\mathrm{ACN}$ & 972 & 1003 & 982 & 999 & -- & 966 \\
\hline $\mathrm{OH}$ & $\mathrm{ACO}$ & 972 & 996 & 977 & 998 & -- & 961 \\
\hline $\mathrm{OH}$ & $2 \mathrm{ACO}$ & 961 & 981 & 957 & 980 & -- & 945 \\
\hline OAc & - & 995 & 1037 & 1025 & 1032 & -- & 993 \\
\hline OAc & $\mathrm{H}_{2} \mathrm{O}$ & 993 & 1017 & 1002 & 1015 & -- & 985 \\
\hline OAc & $\mathrm{NH}_{3}$ & 988 & 1018 & 1002 & 1013 & -- & 976 \\
\hline $\mathrm{OCH}_{3}$ & - & 975 & 1017 & 997 & 1011 & 1018 & 976 \\
\hline $\mathrm{OCH}_{3}$ & $\mathrm{H}_{2} \mathrm{O}$ & 970 & 990 & 975 & 990 & 994 & 961 \\
\hline $\mathrm{OCH}_{3}$ & $\mathrm{NH}_{3}$ & 966 & 995 & 973 & 987 & 994 & 959 \\
\hline
\end{tabular}

4 
1 Table $4 \mathrm{~b}$. Uranyl antisymmetric stretching frequencies $\left(\mathrm{v}_{3}\right)$ for complexes $\left[\mathrm{UO}_{2} \mathrm{AS}_{0,1,2}\right]^{+}$. IRMPD values

2 were generated experimentally, and calculated using LDA and PW91 functionals with various basis sets.

3 All values reported are unscaled.

\begin{tabular}{|c|c|c|c|c|c|c|c|c|}
\hline $\begin{array}{c}\text { A } \\
\text { (anion) }\end{array}$ & $\begin{array}{c}\mathrm{S} \\
\text { (neutral } \\
\text { solvent) }\end{array}$ & $\begin{array}{l}\text { IRMPD } \\
\text { measure- } \\
\text { ments }\end{array}$ & $\begin{array}{l}\text { LDA/ } \\
\text { SVWN/ } \\
\text { DNP }\end{array}$ & $\begin{array}{c}\text { LDA/ } \\
\text { LANL/ } \\
\text { aug-cc- } \\
\text { pvdz }\end{array}$ & $\begin{array}{l}\text { LDA/ } \\
\text { Stuttgart } \\
\text { RSC / } \\
\text { TZVP }\end{array}$ & $\begin{array}{c}\text { PW91/ } \\
\text { LANL / } \\
\text { aug-cc-pvdz }\end{array}$ & $\begin{array}{c}\text { PW91/ } \\
\text { Stuttgart } \\
\text { RSC / } \\
\text { TZVP }\end{array}$ & $\begin{array}{c}\text { ZORA/ } \\
\text { PW91/ } \\
\text { TZ2P }\end{array}$ \\
\hline $\mathrm{OH}$ & - & 971 & 995 & 958 & 1017 & 928 & 987 & 979 \\
\hline $\mathrm{OH}$ & $\mathrm{H}_{2} \mathrm{O}$ & 983 & 973 & 939 & 1001 & 910 & 969 & 959 \\
\hline $\mathrm{OH}$ & $\mathrm{NH}_{3}$ & 976 & 973 & 937 & 990 & 910 & 962 & 958 \\
\hline $\mathrm{OH}$ & $\mathrm{ACN}$ & 972 & 973 & -- & -- & -- & -- & 952 \\
\hline $\mathrm{OH}$ & $\mathrm{ACO}$ & 972 & 968 & -- & -- & -- & -- & 949 \\
\hline $\mathrm{OH}$ & $2 \mathrm{ACO}$ & 961 & 939 & -- & -- & -- & -- & 931 \\
\hline OAc & - & 995 & 995 & -- & -- & -- & -- & 987 \\
\hline OAc & $\mathrm{H}_{2} \mathrm{O}$ & 993 & 984 & - & -- & -- & -- & 970 \\
\hline OAc & $\mathrm{NH}_{3}$ & 988 & 986 & -- & -- & -- & -- & 966 \\
\hline $\mathrm{OCH}_{3}$ & - & 975 & 979 & 949 & 1003 & 920 & 973 & 964 \\
\hline $\mathrm{OCH}_{3}$ & $\mathrm{H}_{2} \mathrm{O}$ & 970 & 961 & 933 & 997 & 904 & 954 & 943 \\
\hline $\mathrm{OCH}_{3}$ & $\mathrm{NH}_{3}$ & 966 & 959 & 932 & 980 & 905 & 950 & 944 \\
\hline
\end{tabular}

5 In contrast, calculations using LDA, PW91, and B3LYP/LANL2dz/aug-cc-pVDZ produced unscaled

6 uranyl $v_{3}$ frequencies that were slightly lower than measurements (Figure 6). . The LDA (calculated

7 using $\mathrm{DMol}^{3}$ ) values (Figure 6, open squares) for the $\left[\mathrm{UO}_{2} \mathrm{~A}\right]^{+}$complexes and those with a N-donating

8 neutral were in good agreement with measurement, with the salient exception of $\left[\mathrm{UO}_{2} \mathrm{OH}\right]^{+}$. Compared

9 to experiments, the LDA values for anion complexes with O-donating ligands were systematically lower 
1 than values for complexes with $\mathrm{N}$-donors, by about $10 \mathrm{~cm}^{-1}$. The value calculated for the

$2\left[\mathrm{UO}_{2} \mathrm{OH}(\mathrm{ACO})_{2}\right]^{+}$was ca. $20 \mathrm{~cm}^{-1}$ lower than the measured value.

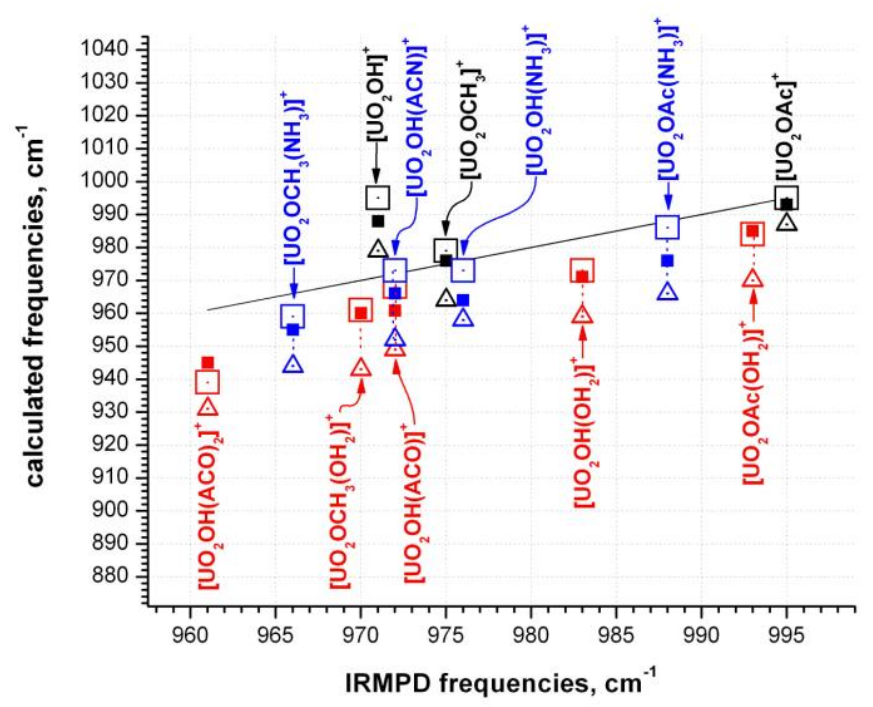

4 Figure 6. Unscaled uranyl $v_{3}$ frequencies calculated using B3LYP/LANL2dz/aug-cc-pVDZ, LDA/VWN 5 and ZORA/PW91/TZ2P, plotted versus IRMPD measurements. The line represents the experimental data.

6 The open squares were generated using LDA/VWN, the filled squares B3LYP/LANL2dz/aug-cc-pVDZ, 7 and the triangles ZORA/PW91/TZ2P. The black points represent $\left[\mathrm{UO}_{2} \mathrm{~A}\right]^{+}$complexes with no neutral 8 donor, red correspond to complexes with O-coordinating neutrals, and blue to those with N-coordinating 9 neutrals.

10 The values calculated using B3LYP in Figure 6 (filled squares) differed from those in Figure 5 in that 11 they were generated using the LANL2dz/aug-cc-pVDZ basis sets. Values calculated for the uranyl 12 methoxide and acetate complexes without neutrals agreed well with the measured values; the hydroxide 13 species was on the order of $18 \mathrm{~cm}^{-1}$ higher. The $\left[\mathrm{UO}_{2} \mathrm{AS}\right]^{+}$complexes were all on the order of 7-15 $\mathrm{cm}^{-1}$ 14 lower than the measurements, and there was no apparent systematic difference between the complexes 15 containing O-donors and those with N-donors, which indicated that B3LYP/LANL2dz/aug-cc-pVDZ 16 predicted shifts resulting from both types of ligands consistently. 
The frequencies were also computed with ZORA/PW91/TZ2P. The results are consistently lower than the pseudopotential LDA/VWN or B3LYP/LANL2dz/aug-cc-pVDZ values, a feature that was also observed

3 in our earlier work on the neutral donor ligands. ${ }^{60}$ The ligand induced shifts are very similar to the

4 results obtained with the other approaches, however, and systematic differences between $\mathrm{O}-$ and $\mathrm{N}$ 5 donors were not calculated.

6 Additional insight into the potential interactions from anion binding can be gained by examining the changes in the calculated bond lengths and angles, which would also check the internal consistency of

8 the predicted stretching frequencies. We selected the calculations performed using B3LYP/SDD/6$931+\mathrm{g}^{* *}$ for discussing relationships between calculated bond lengths and frequencies, which are listed in 10 Table 3, and trends in bond lengths with varying ligation are depicted graphically in Figure 7 (detailed 11 structural parameters generated using B3LYP with three different basis sets are contained in 12 Supplementary Tables S1 - S12, and visual representations are provided in Figures 7 - 9). As ligands 13 are added, calculations show that all distances within the uranyl coordination sphere increase. The 14 magnitude of the increase depends not only on the nucleophilic strength of the different ligands but also 15 on their volumes, and the calculations provide a means to develop a more quantitative assessment of the 16 effect of ligand addition to uranyl. The $\mathrm{O}=\mathrm{U}=\mathrm{O}$ bond length is represented by the lower three traces, 17 and the effect of the anion $\mathrm{A}$, and subsequent addition of a neutral solvent $\mathrm{S}$ is very similar for the 18 acetate, the hydroxy and the methoxide complexes. The uranyl bond elongates by $0.042 \AA, 0.044$, and $190.048 \AA$ for $\mathrm{OAc}^{-}, \mathrm{OH}^{-}$and $\mathrm{OCH}_{3}{ }^{-}$, respectively. This is also the order of increasing anion basicity, 20 resulting in donation of more electron density to the uranium atom, and attendant repulsion of the axial 21 oxygen atoms. The amount of donation was quantified by performing charge analysis calculations with 22 ZORA/PW91/TZ2P. The Hirshfeld method shows donation to uranyl of 0.56e $(\mathrm{OAc}), 0.53 \mathrm{e}(\mathrm{OH})$, and $230.65 \mathrm{e}\left(\mathrm{OCH}_{3}\right)$ while the VDD method gives very similar values of $0.53,052$ and $0.63 \mathrm{e}$, respectively. 


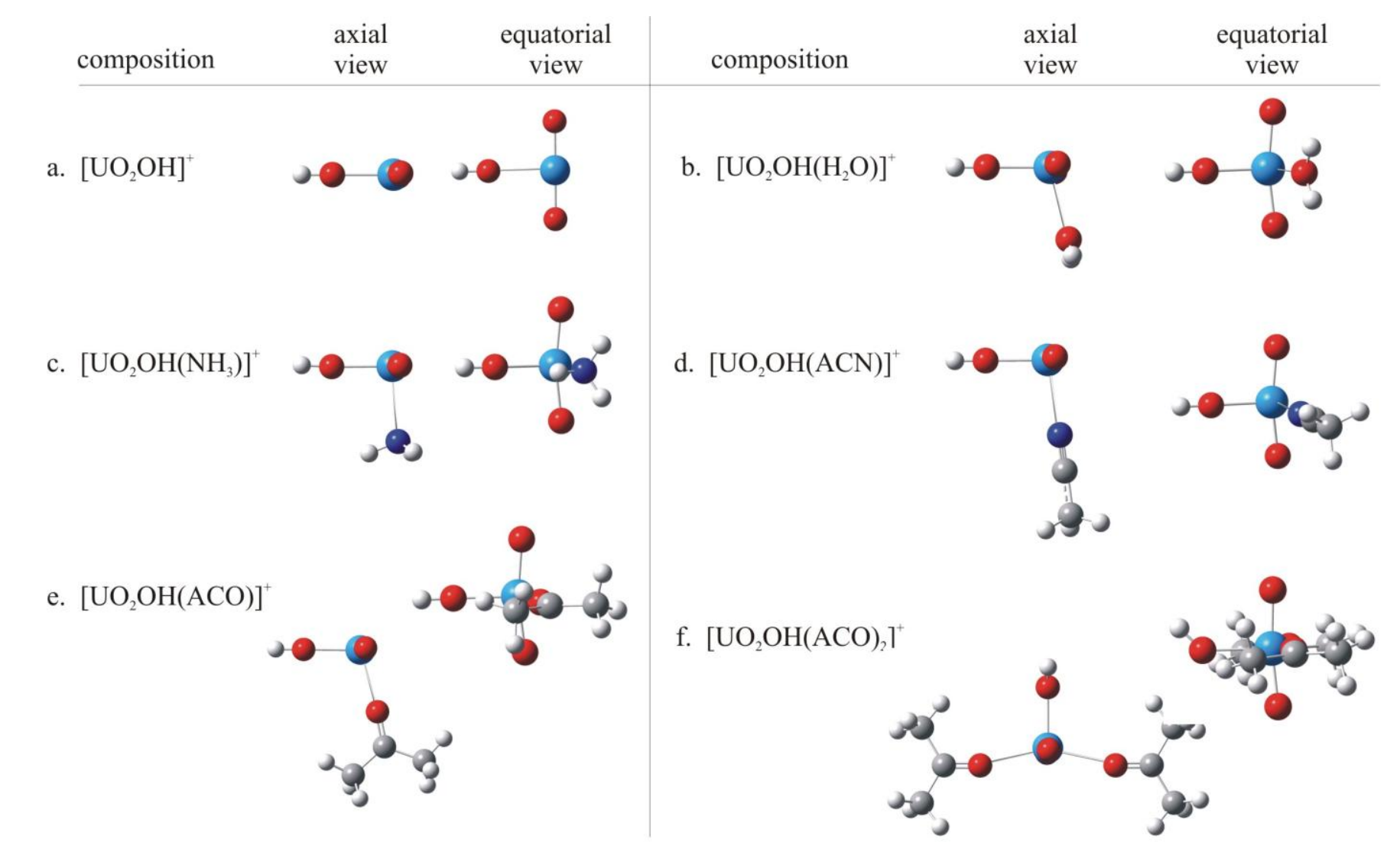

2 Figure 7. Lowest energy conformations of calculated for $\left[\mathrm{UO}_{2} \mathrm{OH}\right]^{+}$and its solvated complexes.

3 Calculations were performed using hybrid B3LYP functional with the SDD basis set on U and 3-21g* 4 on $\mathrm{C}, \mathrm{H}, \mathrm{N}$ and $\mathrm{O}$. 


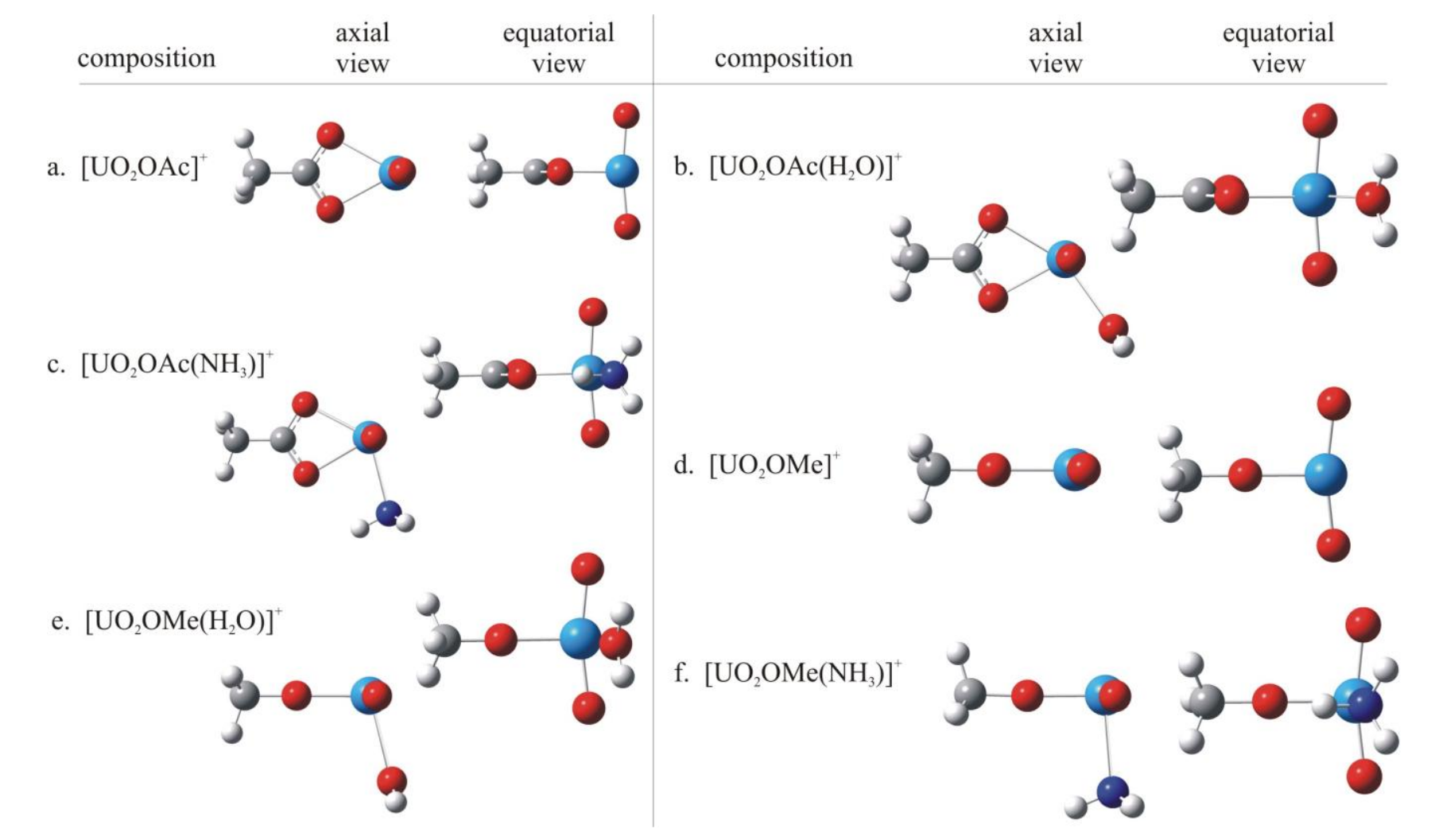

2 Figure 8. Lowest energy conformations of $\left[\mathrm{UO}_{2} \mathrm{OAc}\right]^{+},\left[\mathrm{UO}_{2} \mathrm{OMe}\right]^{+}$and their solvent complexes with

3 water and ammonia. Calculations were performed using hybrid B3LYP functional with the SDD basis 4 set on $\mathrm{U}$ and $3-21 \mathrm{~g} *$ on $\mathrm{C}, \mathrm{H}, \mathrm{N}$ and $\mathrm{O}$. 
1 Table 3. Bond lengths (Angstroms) and $\mathrm{O}=\mathrm{U}=\mathrm{O}$ bond angles for $\left[\mathrm{UO}_{2} \mathrm{AS}\right]^{+}$complexes, calculated using

2 Gaussian 03, at the B3LYP level of theory. The MWB60 (SDD) basis set was used for U, and 3-21g* 3 for $\mathrm{C}, \mathrm{H}, \mathrm{N}$ and $\mathrm{O}$.

\begin{tabular}{|c|c|c|c|c|c|}
\hline A (anion) & $\begin{array}{l}\text { S (neutral } \\
\text { solvent) }\end{array}$ & $\begin{array}{c}\mathrm{U}=\mathrm{O} \text { length, } \\
\AA\end{array}$ & U-anion length, $\AA$ & U-neutral length, $\AA$ & $\mathrm{O}=\mathrm{U}=\mathrm{O}$ angle \\
\hline $\begin{array}{l}{\left[\mathrm{UO}_{2}\right]^{2+},} \\
\text { unligated }\end{array}$ & $\mathrm{n} / \mathrm{a}$ & 1.7002 & $\mathrm{n} / \mathrm{a}$ & $\mathrm{n} / \mathrm{a}$ & 179.578 \\
\hline OAc & $\mathrm{n} / \mathrm{a}$ & 1.7444 & 2.2687 & $\mathrm{n} / \mathrm{a}$ & 170.346 \\
\hline OAc & $\mathrm{H}_{2} \mathrm{O}$ & 1.7735 & 2.2968 & 2.4616 & 171.024 \\
\hline OAc & $\mathrm{NH}_{3}$ & 1.7540 & 2.3015 & 2.5566 & 171.716 \\
\hline $\mathrm{OH}$ & $\mathrm{n} / \mathrm{a}$ & 1.7450 & 2.0104 & $\mathrm{n} / \mathrm{a}$ & 167.409 \\
\hline $\mathrm{OH}$ & $\mathrm{H}_{2} \mathrm{O}$ & 1.7546 & 2.0277 & 2.4416 & 167.606 \\
\hline $\mathrm{OH}$ & $\mathrm{NH}_{3}$ & 1.7581 & 2.0332 & 2.5437 & 167.245 \\
\hline $\mathrm{OH}$ & $\mathrm{ACN}$ & 1.7571 & 2.0318 & 2.4771 & 166.983 \\
\hline $\mathrm{OH}$ & $\mathrm{ACO}$ & 1.7592 & 2.0052 & 2.3252 & 169.898 \\
\hline $\mathrm{OH}$ & $(\mathrm{ACO})_{2}$ & 1.7682 & 2.0828 & 2.3931 & 172.640 \\
\hline $\mathrm{OCH}_{3}$ & $\mathrm{n} / \mathrm{a}$ & 1.7510 & 1.9986 & $\mathrm{n} / \mathrm{a}$ & 167.237 \\
\hline $\mathrm{OCH}_{3}$ & $\mathrm{H}_{2} \mathrm{O}$ & 1.7618 & 2.0167 & 2.4514 & 167.559 \\
\hline $\mathrm{OCH}_{3}$ & $\mathrm{NH}_{3}$ & 1.7633 & 2.0211 & 2.5561 & 167.187 \\
\hline
\end{tabular}




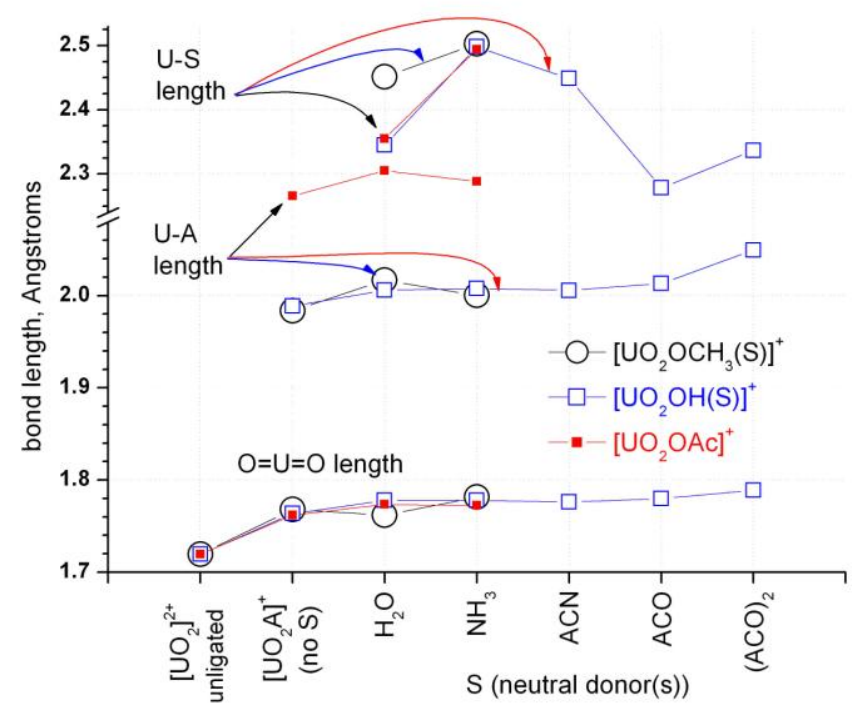

2 Figure 9. Bond lengths plotted versus neutral for $\left[\mathrm{UO}_{2} \mathrm{AS}\right]^{+}$complexes. Values for unligated $\left[\mathrm{UO}_{2}\right]^{2+}$ 3 and $\left[\mathrm{UO}_{2} \mathrm{~A}\right]^{+}$complexes are also included. Values were calculated using B3LYP (Gaussian) with the 4 SDD/3-21g* basis set. (Note break in Y axis at $2.08 \AA$. .)

5 The addition of a neutral donor to the uranyl anion complexes induces a further lengthening of the 6 uranyl bonds (Figure 9), by 0.011 to $0.016 \AA$, with the largest shifts occurring for the more basic 7 neutrals: in this study addition of $\mathrm{ACO}$ caused the largest $\mathrm{O}=\mathrm{U}=\mathrm{O}$ elongation, consistent with the low 8 uranyl frequency measured in the IRMPD spectrum. The magnitude of the elongation on addition of a 9 neutral is much less than that calculated for the initial attachment of the anion. Hirshfeld analysis 10 showed that the strongest donating neutral species, acetone, donates $0.17 \mathrm{e}$ (for one acetone) or $0.25 \mathrm{e}$ 11 (for two acetones) to an uranylhydroxide unit in the $\left[\mathrm{UO}_{2} \mathrm{OH}(\mathrm{ACO})_{1,2}\right]^{+}$complexes (which have the 12 greatest $\mathrm{O}=\mathrm{U}=\mathrm{O}$ elongation); these values are significantly lower than those calculated for the anions.

13 The calculations also predict that the uranium-anion distance will be lengthened by addition of a 14 neutral ligand, which is shown by the middle three traces in Figure 9. Increases ranging from 0.017 to $150.024 \AA$ occurred in the U-OH length for the hydroxide complexes, with the magnitude depending on 16 the basicity of the neutral, and the largest elongation being for addition of ACO. When a second ACO is 
1 added, the U-OH distance elongates by another $0.036 \AA$. The $\mathrm{U}-\mathrm{OCH}_{3}$ bond distance experiences very

2 nearly identical increases upon addition of $\mathrm{H}_{2} \mathrm{O}$ and $\mathrm{NH}_{3}$ to $\left[\mathrm{UO}_{2} \mathrm{OCH}_{3}\right]^{+}$. The U-anion distance

3 calculated for the acetate complex is substantially longer than that for either the hydroxide or the

4 methoxide, and the B3LYP calculations indicated a bidentate-bound acetate, although LDA/VWN

5 suggested a monodentate structure. Using either approach, the U-acetate length is nearly $0.27 \AA$ longer

6 than for the hydroxide or methoxide. Addition of $\mathrm{H}_{2} \mathrm{O}$ or $\mathrm{NH}_{3}$ to the complex causes elongation of the

7 U-acetate bonds by $\sim 0.04$ and $0.02 \AA$, respectively. The fact that $\mathrm{H}_{2} \mathrm{O}$ produced a longer U-anion

8 elongation than $\mathrm{NH}_{3}$ is contrary to what would be expected based on calculated coordination energies

$9 \quad\left(\mathrm{NH}_{3} \sim 9 \mathrm{kcal} / \mathrm{mole}\right.$ greater than $\left.\mathrm{H}_{2} \mathrm{O}\right),{ }^{40}$ but may be consistent with the fact that uranyl behaves as a hard 10 acid, ${ }^{6,40}$ interacting more strongly with the oxygen donors.

11 The U-S bond length in $\left[\mathrm{UO}_{2} \mathrm{AS}\right]^{+}$increased when $\mathrm{NH}_{3}$ was substituted for $\mathrm{H}_{2} \mathrm{O}$, for all three anions 12 studied. Further U-neutral bond length comparisons involved only the hydroxide, and decreased in the 13 order $\mathrm{NH}_{3}>\mathrm{ACN}>\mathrm{ACO}$, minimizing at $2.27 \AA$. The trend correlates inversely with increasing ligand 14 nucleophilicity. Addition of a second $\mathrm{ACO}$ as the third equatorial ligand in $\left[\mathrm{UO}_{2} \mathrm{OH}(\mathrm{ACO})_{2}\right]^{+}$loosens

15 the overall complex: the U-neutral bond is lengthened by nearly $0.06 \AA$, and this is accompanied by a

16 lengthening of the $\mathrm{U}-\mathrm{OH}$ bond by $0.036 \AA$, and the $\mathrm{O}=\mathrm{U}=\mathrm{O}$ bond by nearly $0.01 \AA$. As the coordination 17 sphere is completed, distortions of the $\mathrm{O}=\mathrm{U}=\mathrm{O}$ angle from linearity are lessened, and the value 18 approaches $180^{\circ}$.

\section{CONCLUSIONS}

20 The structure of uranium complexes has been a persistent topic of research in the chemical community

21 because the participation of $5 \mathrm{f}, 6 \mathrm{~d}$ and $7 \mathrm{~s}$ orbitals offers a broad array of possible structures and reaction 22 pathways. The desire to understand and then manipulate uranium chemistry has motivated determined 23 investigations of structure and bonding using spectroscopy and computational chemistry. In principle 24 these approaches should be highly complementary, but in practice results from each cannot be correlated 25 with each other because spectroscopy measurements on condensed phase systems almost always 
measure an ensemble of species, while calculations produce data for single discrete species, and do not always include specific and/or long-range interactions with solvent. Consequently it is difficult to use condensed-phase spectroscopic measurements to evaluate computational accuracy, which is badly needed for molecules containing f elements. Infrared spectra of gas phase complexes generated using IRMPD provide data for discrete species that are of great value for evaluating ligand binding trends and computational chemistry results.

Much emphasis has been placed on the study of uranyl dication complexes, and prior IRMPD studies of ACO complexes by our groups enabled comparison of antisymmetric $\mathrm{O}=\mathrm{U}=\mathrm{O}$ and $\mathrm{C}=\mathrm{O}$ frequencies with solution phase measurements and computational results. ${ }^{60}$ However at mid-pH ranges, uranyl-anion pairs are more prevalent and hence in the present study, IRMPD of ion pairs involving hydroxide, acetate and methoxide were examined. The uranyl antisymmetric frequency values were red-shifted equal to or greater than $\mathrm{UO}_{2}{ }^{2+}$ coordinated with four or five neutral donor ligands. While vibrational anharmonicity no doubt contributes to these low frequency values, the intrinsic frequencies of the ion pair complexes are lower than expected when compared with solution phase measurements and with past and present DFT results. The addition of a solvent neutral $\mathrm{S}$ to the ion pairs did not result in systematic decreases in the $v_{3}$ values. But when frequencies for the $\left[\mathrm{UO}_{2} \mathrm{AS}\right]^{+}$species were compared for differing neutrals, the $v_{3}$ value decreased with increasing $\mathrm{S}$ nucleophilicity, consistent with theory, intuition and previous IRMPD results. ${ }^{60}$

The $\left[\mathrm{UO}_{2} \mathrm{OCH}_{3}\right]^{+}$molecule underwent wavelength-specific fragmentation reactions, eliminating the $\mathrm{OCH}_{3}$ radical at a frequency $20 \mathrm{~cm}^{-1}$ lower than fragmentations involving rearrangement and or loss of $\mathrm{H}$ atom(s). DFT modeling suggested that the $\mathrm{OCH}_{3}$ radical loss was activated by absorption at the uranyl stretching frequency, while the $\mathrm{H}$ atom loss/rearrangement eliminations were activated by absorption at the $\mathrm{C}-\mathrm{O}$ stretching frequency. Identifying the cause of this phenomenon remains an outstanding task: IRMPD anharmonicity together with absorption non-linearities (as observed in the spectra of the paraaminobenzoic acid cation ${ }^{58}$ and $\left[\mathrm{CeOH}(\mathrm{ACO})_{\mathrm{n}=3,4}\right]^{2+}$ cation $^{93}$ ) may contribute to the phenomenon, 
1 however the very large differences in the different photo-fragmentation channels suggests that there may

2 be another factor at work, such as promotion to an excited state electronic configuration, which would

3 be energetically feasible.

\section{ACKNOWLEDGMENTS}

5 Work by G. S. Groenewold and A. K. Gianotto was supported by the U.S. Department of Energy,

6 Assistant Secretary for Environmental Management, and the INL Laboratory Directed Research \&

7 Development Program under DOE Idaho Operations Office Contract DE-AC07-05ID14517. M. J. Van

8 Stipdonk was supported in part through a grant from the U. S. National Science Foundation (CAREER-

9 0239800). Gaussian 03 calculations were performed at the Wichita State University High-performance

10 Computing Center (HIPECC), a facility supported by the U. S. National Science Foundation under

11 Grant No. EIA-0216178 and Grant No. EPS-0236913, with matching support from the State of Kansas

12 and HIPECC. W. A. de Jong's research was performed, in part, using the Molecular Science Computing

13 Facility in the William R. Wiley Environmental Molecular Sciences Laboratory, a national scientific user facility

14 sponsored by the U.S. Department of Energy's Office of Biological and Environmental Research located at the

15 Pacific Northwest National Laboratory, which is operated for the Department of Energy by Battelle. The FOM

16 authors, Ivan Infante and Lucas Visscher were supported by the Nederlandse Organisatie voor

17 Wetenschappelijk Onderzoek (Dutch National Science Foundation). The skillful assistance by the

18 FELIX staff, in particular Dr. B. Redlich, is gratefully acknowledged. Construction and shipping of the

19 FTMS instrument was made possible through funding from the National High Field FT-ICR Facility

20 (grant CHE-9909502) at the National High Magnetic Field Laboratory, Tallahassee, FL, as was travel

21 support for one of the INL authors; John Eyler's assistance was particularly invaluable. 
2 Complete listings of structural data calculated using B3LYP with the SDD, and SDD / 3-21g* basis

3 sets are provided in tables $\mathrm{S} 1-\mathrm{S} 7$ in the supplementary information. Visual representations are also 4 provided, in Figures S1-S4. Complete citations for references 73 and 80 are also included. The material 5 is available free of charge on the Internet at http: I|pubs.acs.org.

6

21 New York, 1984.

22

\section{REFERENCES} pp 559.

(1) Choppin, G. R.; Rizkalla, E. N. Solution Chemistry of Actinides and Lanthanides. In Handbook on the Physics and Chemistry of Rare Earths; Gschneider, J., K. A., Eyring, L., Choppin, G. R., Lander, G. H., Eds.; North-Holland: Amsterdam, 1994; Vol. 18-Lanthanides/Actinides: Chemistry;

(2) Denning, R. G. Struct. Bond. 1992, 79, 215.

(3) Pepper, M.; Bursten, B. E. Chem. Rev. 1991, 91, 719.

(4) Matsika, S.; Zhang, Z.; Brozell, S. R.; Blaudeau, J.-P.; Wang, Q.; Pitzer, R. M. J. Phys. Chem. A 2001, 105, 3825 .

(5) Silva, R. J.; Nitsche, H. Radiochim. Acta 1995, 70/71, 377

(6) Morse, J. W.; Choppin, G. R. Rev. Aquatic Sci. 1991, 4, 1.

(7) Toth, L. M.; Begun, G. M. J. Phys. Chem. 1981, 85, 547.

(8) Burgess, J. Metal Ions in Solution; Ellis Horwood Limited: Chichester, UK, 1978.

(9) Choppin, G. Radiochim. Acta 2004, 92, 519.

(10) Brookins, D. G. Geochemical Aspects of Radioactive Waste Disposal; Springer-Verlag:

(11) Rizkalla, E. N.; Choppin, G. R. Lanthanides and Actinides Hydration and Hydrolysis. In Handbook on the Physics and Chemistry of Rare Earths. Volume 18: Lanthanides/Actinides: 
1 Chemistry; Gschneidner, J., K. A., Eyring, L., Choppin, G. R., Lander, G. H., Eds.; North-Holland: New

$2 \quad$ York, 1994; Vol. 18; pp 529.

(12) Nguyen-Trung, C.; Palmer, D. A.; Begun, G. M.; Peiffert, C.; Mesmer, R. E. J. Solut.

Chem. 2000, 29, 101.

(13) Brooker, M. H.; Huang, C.-H.; Sylwestrowicz, J. J. Inorg. Nucl. Chem. 1980, 42, 1431.

(14) Glebov, V. A. Koord. Khim. 1982, 8, 970.

(15) Nguyen-Trung, C.; Begun, G. M.; Palmer, D. A. Inorg. Chem. 1992, 31, 5280.

(16) Jones, L. H. Spectrochim. Acta 1958, 10, 395

(17) Quiles, F.; Burneau, A. Vib. Spectrosc. 1998, 18, 61.

(18) Gal, M.; Goggin, P. L.; Mink, J. J. Mol. Struct. 1984, 114, 459.

(19) McGlynn, S. P.; Smith, J. K.; Neely, W. C. J. Chem. Phys. 1961, 35, 105.

(20) Jones, L. H.; Penneman, R. A. J. Chem. Phys. 1953, 21, 542.

(21) Best, S. P.; Clark, R. J. H.; Cooney, R. P. Inorg. Chim. Acta 1988, 145, 141.

(22) Clark, D. L.; Conradson, S. D.; Donohoe, R. J.; Keogh, D. W.; Morris, D. E.; Palmer, P.

D.; Rogers, R. D.; Tait, C. D. Inorg. Chem. 1999, 38, 1456.

(23) Kakihana, M.; Nagumo, T.; Okamoto, M.; Kakihana, H. J. Phys. Chem. 1987, 91, 6128.

(24) Mizuoka, K.; Ikeda, Y. Radiochim. Acta 2004, 92, 631.

(25) Burns, C. J.; Smith, C. C.; Sattelberger, A. P.; Gray, H. B. Inorg. Chem. 1992, 31, 3724.

(26) Morris, D. E.; Chisholm-Brause, C. J.; Barr, M. E.; Conradson, S. D.; Gary Eller, P.

Geochim. Cosmochim. Acta 1994, 58, 3613.

(27) Duff, M. C.; Coughlin, J. U.; Hunter, D. B. Geochim. Cosmochim. Acta 2002, 66, 3533.

(28) Tellez Soto, C. A.; Arissawa, M.; Gomez, L., J.; Mondragon, M. A. Polyhedron 2000, 19, 2353.

(29) Madic, C.; Hobart, D. E.; Begun, G. M. Inorg. Chem. 1983, 22, 1494.

(30) Glebov, V. A. Koord. Khim. 1981, 7, 388. 
(31) Mizuoka, K.; Ikeda, Y. Inorg. Chem. 2003, 42, 3396.

(32) Basile, L. J.; Sullivan, J. C.; Ferraro, J. R.; LaBonville, P. Appl. Spectrosc. 1974, $28,142$.

(33) Schreckenbach, G.; Hay, P. J.; Martin, R. L. J. Comput. Chem. 1999, 20, 70.

(34) Vetere, V.; Maldivi, P.; Adamo, C. J. Comput. Chem. 2003, 24, 850.

(35) Van Wullen, C. J. Comput. Chem. 1999, 20, 51.

(36) Kaltsoyannis, N. Chem. Soc. Rev. 2003, 32, 9.

(37) de Jong, W. A.; Harrison, R. J.; Nichols, J. A.; Dixon, D. A. Theor. Chem. Acc. 2001, 107, 22.

(38) Clavaguera-Sarrio, C.; Ismail, N.; Marsden, C. J.; Begue, D.; Pouchan, C. Chem. Phys. 2004, 302, 1 .

(39) Hay, P. J.; Martin, R. L.; Schreckenbach, G. J. Phys. Chem. A 2000, 104, 6259.

(40) Clavaguera-Sarrio, C.; Hoyau, S.; Ismail, N.; Marsden, C. J. J. Phys. Chem. A 2003, 107, 4515.

(41) Farkas, I.; Banyai, I.; Szabo, Z.; Wahlgren, U.; Grenthe, I. Inorg. Chem. 2000, 39, 799.

(42) Gutowski, K. E.; Dixon, D. A. J. Phys. Chem. A 2006, 110, 8840.

(43) Gutowski, K. E.; Cocalia, V. A.; Griffin, S. T.; Bridges, N. J.; Dixon, D. A.; Rogers, R. D. J. Am. Chem. Soc. 2007, 129, 526.

(44) Duncan, M. A. Int. Rev. Phys. Chem. 2003, 22, 407.

(45) Lemaire, J.; Boissel, P.; Heninger, M.; Mauclaire, G.; Bellec, G.; Mestdagh, H.; Simon, A.; Le Caer, S.; Ortega, J. M.; Glotin, F.; Maitre, P. Phys. Rev. Lett. 2002, 89.

(46) Moore, D. T.; Oomens, J.; Eyler, J. R.; Meijer, G.; von Helden, G.; Ridge, D. P. J. Am. Chem. Soc. 2004, 126, 14726.

(47) Oepts, D.; van der Meer, A. F. G.; van Amersfoort, P. W. Infrared Phys. Technol. 1995, 36, 297. 
64.

21710. 527.

(49) Schroder, D.; Roithova, J.; Schwarz, H. Int. J. Mass Spectrom. 2006, 254, 197.

(50) Stewart, I. I. Spectrochim. Acta, Part B 1999, 54, 1649.

(51) Gatlin, C. L.; Turecek, F. Electrospray Ionization of Inorganic and Organometallic Complexes. In Electrospray Ionization Mass Spectrometry; John Wiley \& Sons: New York, 1997; pp

(52) Chien, W.; Anbalagan, V.; Zandler, M.; Hanna, D.; Van Stipdonk, M.; Gresham, G.; Groenewold, G. J. Amer. Soc. Mass Spectrom. 2004, 15, 777.

(53) Van Stipdonk, M.; Anbalagan, V.; Chien, W.; Gresham, G.; Groenewold, G.; Hanna, D. J. Am. Soc. Mass Spectrom. e2003, 14, 1205.

(54) Van Stipdonk, M. J.; Chien, W.; Angalaban, V.; Bulleigh, K.; Hanna, D.; Groenewold, G. S. J. Phys. Chem. A 2004, 108, 10448.

(55) Van Stipdonk, M. J.; Chien, W.; Bulleigh, K.; Wu, Q.; Groenewold, G. S. J. Phys. Chem. A 2006, 110, 959.

(56) Oomens, J.; Sartakov, B. G.; Meijer, G.; von Helden, G. Int. J. Mass Spectrom. 2006, $254,1$.

(57) Moore, D. T.; Oomens, J.; van der Meer, L.; von Helden, G.; Meijer, G.; Valle, J.; Marshall, A. G.; Eyler, J. R. ChemPhysChem 2004, 5, 740.

(58) Oomens, J.; Moore, D. T.; Meijer, G.; von Helden, G. Phys. Chem. Chem. Phys. 2004, 6,

(59) Oomens, J.; Moore, D. T.; von Helden, G.; Meijer, G.; Dunbar, R. C. J. Am. Chem. Soc. 2004, 126, 724 .

(60) Groenewold, G. S.; Gianotto, A. K.; Cossel, K. C.; Van Stipdonk, M. J.; Moore, D. T.; Polfer, N.; Oomens, J.; de Jong, W. A.; Visscher, L. J. Am. Chem. Soc. 2006, 107, 4802. 
(61) Sachs, S.; Brendler, V.; Geipel, G. Radiochim. Acta 2007, 95, 103.

(62) Valle, J. J.; Eyler, J. R.; Oomens, J.; Moore, D. T.; van der Meer, A. F. G.; von Helden,

G.; Meijer, G.; Hendrickson, C. L.; Marshall, A. G.; Blakney, G. T. Rev. Sci. Instrum. 2005, 76, 023103.

(63) Marshall, A. G.; Wang, T.-C. L.; Ricca, T. L. J. Am. Chem. Soc. 1985, 107, 7893.

(64) Bagratashivili, V. N.; Letokov, V. S.; Makarov, A. A.; Ryabov, E. A. Mutiple Photon Infrared Laser Photophysics and Photochemistry; Harwood: Chur, Switzerland, 1985.

(65) Oomens, J.; Tielens, A. G. G. M.; Sartakov, B. G.; Von Helden, G.; Meijer, G. Astrophys. J. 2003, 591, 968.

(66) Marshall, A. G. Acc. Chem. Res. 1985, 18, 316.

(67) Marshall, A. G.; Hendrickson, C. L.; Jackson, G. S. Mass Spectrom. Rev. 1998, 17, 1.

(68) Slater, J. C. Phys. Rev. Lett. 1951, 81, 385.

(69) Vosko, S. J.; Wilk, W.; Nusair, M. Can. J. Phys. 1980, 58, 1200.

(70) Delley, B. J. Chem. Phys. 1990, 92, 508.

(71) Delley, B. J. Chem. Phys. 2000, 113, 7756.

(72) Delley, B. Int. J. Quantum Chem. 1998, 69, 423.

(73) Becke, A. D. J. Chem. Phys. 1993, 98, 5648.

(74) Lee, C. T.; Yang, W. T.; Parr, R. G. Phys. Rev. B 1988, 37, 785.

(75) Aprà, E.; et.al. NWChem, A Computational Chemistry Package for Parallel Computers; Version 4.7 ed.; Pacific Northwest National Laboratory: Richland, Washington 99352-0999, USA, 2005.

(76) Kendall, R. A.; Apra, E.; Bernholdt, D. E.; Bylaska, E. J.; Dupuis, M.; Fann, G. I.; Harrison, R. J.; Ju, J.; Nichols, J. A.; Nieplocha, J.; Straatsma, T. P.; Windus, T. L.; Wong, A. T. Computer Phys. Comm. 2000, 128, 260.

(77) Frisch, M. J.; Trucks, G. W.; Schlegel, H. B.; Scuseria, G. E.; Robb, M. A.; Cheeseman, J. R.; Zakrzewski, V. G.; Montgomery, J. A. J.; Stratmann, R. E.; Burant, J. C.; Dapprich, S.; Millam, J. 
$1 \quad$ M.; Daniels, A. D.; Kudin, K. N.; Strain, M. C.; Farkas, O.; Tomasi, J.; Barone, V.; Cossi, M.; Cammi,

2 R.; Mennucci, B.; Pomelli, C.; Adamo, C.; Clifford, S.; Ochterski, J.; Petersson, G. A.; Ayala, P. Y.;

3 Cui, Q.; Morokuma, K.; Malick, D. K.; Rabuck, A. D.; Raghavachari, K.; Foresman, J. B.; Cioslowski, 4 J.; Ortiz, J. V.; Stefanov, B. B.; Liu, G.; Liashenko, A.; Piskorz, P.; Komaromi, I.; Gomperts, R.; 5 Martin, R. L.; Fox, D. J.; Keith, T.; Al-Laham, M. A.; Peng, C. Y.; Nanayakkara, A.; Gonzalez, C.; 6 Challacombe, M.; Gill, P. M. W.; Johnson, B.; Chen, W.; Wong, M. W.; Andres, J. L.; Gonzalez, C.; 7 Head-Gordon, M.; Replogle, E. S.; Pople, J. A. Gaussion 98, Revision A.4; Gaussian, Inc.. Pittsburgh, $8 \quad$ PA, 1998.

9

(78) Ortiz, J. V.; Hay, P. J.; Martin, R. L. J. Am. Chem. Soc. 1992, 114, 2736.

(79) Dunning, T. H. J. Chem. Phys. 1989, 90, 1007.

(80) Chaban, G. M.; Jung, J. O.; Gerber, R. B. J. Chem. Phys. 1999, 111, 1823.

(81) Matsunaga, N.; Chaban, G. M.; Gerber, R. B. J. Chem. Phys. 2002, 117, 3541.

(82) Yagi, K.; Hirao, K.; Taketsugu, T.; Schmidt, M. W.; Gordon, M. S. J. Chem. Phys. 2004, $121,1383$.

(83) Bergner, A.; Dolg, M.; Kuchle, W.; Stoll, H.; Preuss, H. Mol. Phys. 1993, 80, 1431.

(84) Dolg, M. Modern Methods and Algorithms of Quantum Chemistry; John von Neumann Institute for Computing: Julich, Germany, 2000; Vol. 1.

(85) Dunning, T. H., Jr.; Hay, P. H. Modern Theoretical Chemistry; Plenum: New York, 1976; Vol. 3.

(86) Kuchle, W.; Dolg, M.; Stoll, H.; Preuss, H. Mol. Phys. 1991, 74, 1245.

(87) te Velde, G.; Bickelhaupt, F. M.; Baerends, E. J.; Guerra, C. F.; Van Gisbergen, S. J. A.; Snijders, J. G.; Ziegler, T. J. Comput. Chem. 2001, 22, 931.

(88) van Lenthe, E.; Baerends, E. J.; Snijders, J. G. J. Chem. Phys. 1993, 99, 4597.

(89) Perdew, J. P.; Chevary, J. A.; Vosko, S. H.; Jackson, K. A.; Pederson, M. R.; Singh, D. J.; Fiolhais, C. 1992, 46, 6671. 
9

(90) Soderholm, L.; Skanthakumar, S.; Neuefeind, J. Anal. Bioanal. Chem. 2005, 383, 48.

(91) Neuefeind, J.; Soderholm, L.; Skanthakumar, S. J. Phys. Chem. A 2004, 108, 2733.

(92) Quiles, F.; Burneau, A. Vib. Spectrosc. 2000, 23, 231.

(93) Groenewold, G. S.; Gianotto, A. K.; Cossel, K. C.; Van Stipdonk, M. J.; Oomens, J.;

Polfer, N.; Moore, D. T.; de Jong, W. A.; McIlwain, M. E. Phys. Chem. Chem. Phys. 2006, 9, 596.

(94) Kasha, M. J. Chem. Phys. 1949, 17, 349.

(95) Lias, S. G. NIST Chemistry WebBook; United States Department of Commerce, National Institute of Standards and Technology, 2003; Vol. 2004.

(96) de Jong, W. A.; Apra, E.; Windus, T. L.; Nichols, J. A.; Harrison, R. J.; Gutowski, K. E.;

Dixon, D. A. J. Phys. Chem. A 2005, 109, 11568.

(97) Rodgers, M. T.; Armentrout, P. B. Mass Spectrom. Rev. 2000, 19, 215.

(98) Banisaukas, J.; Szczepanski, J.; Eyler, J. R.; Vala, M.; Hirata, S.; Head-Gordon, M.;

Oomens, J.; Meijer, G.; von Helden, G. J. Phys. Chem. A 2003, 107, 782.

(99) Fielicke, A.; Mitric, R.; Meijer, G.; Bonacic-Koutecky, V.; von Helden, G. J. Am. Chem. Soc. 2003, 125, 15716.

(100) Forsman, J. B.; Frisch, A. E. Exploring Chemistry with Electronic Structure Methods, 2nd ed.; Gaussian: Pittsburgh, PA, 1996.

(101) Langhoff, S. R. J. Phys. Chem. 1996, 100, 2819. 
8 Table S1. Unscaled frequencies for $\left[\mathrm{UO}_{2}\right]^{2+}$ and $\left[\mathrm{UO}_{2} \mathrm{~A}\right]^{+}$complexes, calculated using B3LYP and the $9 \quad$ SDD (MWB60) basis set for all atoms.

\begin{tabular}{|c|c|c|c|}
\hline A (anion) & $\begin{array}{c}\text { Antisymmetric } \mathrm{O}=\mathrm{U}=\mathrm{O} \\
\text { Stretch }\left(v_{3}\right), \mathrm{cm}^{-1}\end{array}$ & $\begin{array}{c}\text { Symmetric } \mathrm{O}=\mathrm{U}=\mathrm{O} \\
\text { Stretch }\left(v_{1}\right), \mathrm{cm}^{-1}\end{array}$ & Other \\
\hline$\left[\mathrm{UO}_{2}\right]^{2+}$ & 1120.30 & - & 157.42 \\
\hline $\mathrm{OAc}$ & 1025.08 & 936.23 & $701.70(\mathrm{U}-\mathrm{O})$ \\
\hline $\mathrm{OH}$ & 1009.46 & 926.75 & $1029.72\left(\mathrm{O}-\mathrm{CH}_{3}\right)$ \\
\hline $\mathrm{OCH}_{3}$ & 996.53 & 905.71 & \\
\hline
\end{tabular}

10 
1 Table S2. Unscaled frequencies for $\left[\mathrm{UO}_{2} \mathrm{AS}\right]^{+}$complexes. calculated using calculated using B3LYP

2 and the SDD (MWB60) basis set for all atoms.

\begin{tabular}{|c|c|c|c|c|}
\hline A (anion) & $\mathrm{S}$ (neutral) & $\begin{array}{c}\text { Antisymmetric } \\
\mathrm{O}=\mathrm{U}=\mathrm{O} \text { Stretch } \\
\left(\mathrm{v}_{3}\right), \mathrm{cm}^{-1}\end{array}$ & $\begin{array}{c}\text { Symmetric } \\
\mathrm{O}=\mathrm{U}=\mathrm{O} \text { Stretch } \\
\left(\mathrm{v}_{1}\right), \mathrm{cm}^{-1}\end{array}$ & Other \\
\hline $\mathrm{OH}$ & $\mathrm{H}_{2} \mathrm{O}$ & 986.06 & 905.13 & $683.38(\mathrm{U}-\mathrm{OH})$ \\
\hline & $\mathrm{NH}_{3}$ & 984.23 & 903.71 & $685.28(\mathrm{U}-\mathrm{OH})$ \\
\hline & $\mathrm{ACN}$ & & & $666.76(\mathrm{U}-\mathrm{OH})$ \\
\hline & $\mathrm{ACO}$ & 977.01 & 896.07 & $638.17(\mathrm{U}-\mathrm{OH})$ \\
\hline $\mathrm{OCH}_{3}$ & $(\mathrm{ACO})_{2}$ & 956.65 & - & 1054.48 \\
\hline & $\mathrm{H}_{2} \mathrm{O}$ & 974.85 & 886.98 & 1056.86 \\
\hline $\mathrm{OAc}$ & $\mathrm{NH}_{3}$ & 973.09 & 885.89 & - \\
\hline & $\mathrm{H}_{2} \mathrm{O}$ & 1001.69 & 914.06 & - \\
\hline & $\mathrm{NH}_{3}$ & 1002.08 & 914.76 & \\
\hline
\end{tabular}

4 Table S3. Bond lengths (Angstroms) and $\mathrm{O}=\mathrm{U}=\mathrm{O}$ bond angles for $\left[\mathrm{UO}_{2}\right]^{2+}$ and $\left[\mathrm{UO}_{2} \mathrm{~A}\right]^{+}$complexes.

5 calculated using B3LYP and the SDD (MWB60) basis set for all atoms.

\begin{tabular}{|c|c|c|c|}
\hline $\begin{array}{c}\text { A (anion) } \\
\begin{array}{c}{\left[\mathrm{UO}_{2}\right]^{2+}} \\
\text { unligated }\end{array}\end{array}$ & $\mathrm{U}=\mathrm{O}$ length, $\AA$ & $\mathrm{U}-\mathrm{O}$ length (U to anion), $\AA$ & $\mathrm{O}=\mathrm{U}=\mathrm{O}$ angle \\
\hline $\mathrm{OAc}$ & 1.7167 & - & 180.0 \\
\hline $\mathrm{OH}$ & 1.7609 & 2.2705 & 169.656 \\
\hline $\mathrm{OCH}_{3}$ & 1.7630 & 2.0008 & 166.912 \\
\hline
\end{tabular}


1 Table S4. Bond lengths (Angstroms) and $\mathrm{O}=\mathrm{U}=\mathrm{O}$ bond angles for $\left[\mathrm{UO}_{2} \mathrm{AS}\right]^{+}$complexes. calculated 2 using B3LYP and the SDD (MWB60) basis set for all atoms.

\begin{tabular}{|c|c|c|c|c|c|}
\hline A (anion) & $\mathrm{S}$ (neutral) & $\begin{array}{c}\mathrm{U}=\mathrm{O} \text { length, } \\
\AA\end{array}$ & $\begin{array}{c}\text { U-anion } \\
\text { length, } \AA\end{array}$ & $\begin{array}{c}\text { U-ligand } \\
\text { length, } \AA\end{array}$ & $\mathrm{O}=\mathrm{U}=\mathrm{O}$ angle \\
\hline $\mathrm{OH}$ & $\mathrm{H}_{2} \mathrm{O}$ & 1.7763 & 2.0197 & 2.3869 & 166.982 \\
\hline & $\mathrm{NH}_{3}$ & 1.7773 & 2.0237 & 2.5085 & 166.566 \\
\hline & $\mathrm{ACN}$ & & & & \\
\hline & $\mathrm{ACO}$ & 1.7795 & 2.0303 & 2.2863 & 167.059 \\
\hline & $(\mathrm{ACO})_{2}$ & 1.7899 & 2.0556 & 2.3510 & 169.423 \\
\hline $\mathrm{OCH}_{3}$ & $\mathrm{H}_{2} \mathrm{O}$ & 1.7814 & 2.0099 & 2.3954 & 166.803 \\
\hline & $\mathrm{NH}_{3}$ & 1.7822 & 2.0134 & 2.5183 & 166.374 \\
\hline $\mathrm{HAc}_{2}$ & $\mathrm{NH}_{3}$ & 1.7713 & 2.3027 & 2.5104 & 170.651 \\
\hline
\end{tabular}


1 Table S5. Unscaled frequencies for $\left[\mathrm{UO}_{2}\right]^{2+}$ and $\left[\mathrm{UO}_{2} \mathrm{~A}\right]^{+}$complexes, calculated using B3LYP with the

2 SDD (MWB60) basis set for U, and 3-21g* for C, H, N and $\mathrm{O}$.

\begin{tabular}{|c|c|c|c|}
\hline A (anion) & $\begin{array}{c}\text { Antisymmetric } \mathrm{O}=\mathrm{U}=\mathrm{O} \\
\text { stretch }\left(v_{3}\right), \mathrm{cm}^{-1}\end{array}$ & $\begin{array}{c}\text { Symmetric } \mathrm{O}=\mathrm{U}=\mathrm{O} \\
\text { stretch }\left(v_{1}\right), \mathrm{cm}^{-1}\end{array}$ & Other \\
\hline$\left[\mathrm{UO}_{2}\right]^{2+}$ & 1124.69 & - & $183.27(\mathrm{U}-\mathrm{O})$ \\
\hline $\mathrm{OAc}$ & 1036.514 & 945.49 & $734.61(\mathrm{U}-\mathrm{O})$ \\
\hline $\mathrm{OH}$ & 1026.58 & 941.42 & $1041.61(\mathrm{O}-\mathrm{CH} 3)$ \\
\hline $\mathrm{OCH}_{3}$ & 1016.62 & 922.96 & \\
\hline
\end{tabular}

4 Table S6. Unscaled frequencies for $\left[\mathrm{UO}_{2} \mathrm{AS}\right]^{+}$complexes, calculated using B3LYP with the SDD 5 (MWB60) basis set for $\mathrm{U}$, and 3-21g* for $\mathrm{C}, \mathrm{H}, \mathrm{N}$ and $\mathrm{O}$.

\begin{tabular}{|c|c|c|c|c|}
\hline A (anion) & S (neutral) & $\begin{array}{c}\text { Antisymmetric } \\
\mathrm{O}=\mathrm{U}=\mathrm{O} \text { stretch } \\
\quad\left(\mathrm{v}_{3}\right), \mathrm{cm}^{-1}\end{array}$ & $\begin{array}{c}\text { Symmetric } \\
\mathrm{O}=\mathrm{U}=\mathrm{O} \text { stretch } \\
\left(\mathrm{v}_{1}\right), \mathrm{cm}^{-1}\end{array}$ & Other \\
\hline \multirow[t]{5}{*}{$\mathrm{OH}$} & $\mathrm{H}_{2} \mathrm{O}$ & 1002.78 & 919.82 & 715.99 (U-OH) \\
\hline & $\mathrm{NH}_{3}$ & 1002.03 & 919.38 & $717.72(\mathrm{U}-\mathrm{OH})$ \\
\hline & $\mathrm{ACN}$ & 1002.93 & 919.29 & $714.40(\mathrm{U}-\mathrm{OH})$ \\
\hline & $\mathrm{ACO}$ & 996.34 & 913.06 & 705.59 (U-OH) \\
\hline & $(\mathrm{ACO})_{2}$ & 980.77 & 897.11 & $666.29(\mathrm{U}-\mathrm{OH})$ \\
\hline \multirow[t]{2}{*}{$\mathrm{OCH}_{3}$} & $\mathrm{H}_{2} \mathrm{O}$ & 990.49 & 905.25 & $\begin{array}{c}1079.62(\mathrm{U}- \\
\left.\mathrm{OCH}_{3}\right)\end{array}$ \\
\hline & $\mathrm{NH}_{3}$ & 994.66 & 904.73 & $\begin{array}{c}1067.07(\mathrm{U}- \\
\left.\mathrm{OCH}_{3}\right)\end{array}$ \\
\hline \multirow[t]{2}{*}{ OAc } & $\mathrm{H}_{2} \mathrm{O}$ & 1016.66 & 927.48 & - \\
\hline & $\mathrm{NH}_{3}$ & 1017.97 & 928.55 & - \\
\hline
\end{tabular}


1 Table S7. Bond lengths (Angstroms) and $\mathrm{O}=\mathrm{U}=\mathrm{O}$ bond angles for $\left[\mathrm{UO}_{2}\right]^{2+}$ and $\left[\mathrm{UO}_{2} \mathrm{~A}\right]^{+}$complexes,

2 calculated using B3LYP with the SDD (MWB60) basis set for U, and 3-21g* for C, H, N and O.

\begin{tabular}{|c|c|c|c|}
\hline A (anion) & $\mathrm{U}=\mathrm{O}$ length, $\AA$ & $\mathrm{U}-\mathrm{O}$ length (U to ligand), $\AA$ & $\mathrm{O}=\mathrm{U}=\mathrm{O}$ angle \\
\hline$\left[\mathrm{UO}_{2}\right]^{2+}$ unligated & 1.7193 & - & 180.000 \\
\hline $\mathrm{OAc}$ & 1.7617 & 2.2658 & 170.628 \\
\hline $\mathrm{OH}$ & 1.7636 & 1.9887 & 167.618 \\
\hline $\mathrm{OCH}_{3}$ & 1.7681 & 1.9835 & 167.555 \\
\hline
\end{tabular}

4 Table S8. Bond lengths (Angstroms) and $\mathrm{O}=\mathrm{U}=\mathrm{O}$ bond angles for $\left[\mathrm{UO}_{2} \mathrm{AS}\right]^{+}$complexes, calculated 5 using B3LYP with the SDD (MWB60) basis set for U, and 3-21g* for C, H, N and O.

\begin{tabular}{|c|c|c|c|c|c|}
\hline A (anion) & $\mathrm{S}$ (neutral) & $\begin{array}{c}\mathrm{U}=\mathrm{O} \text { length, } \\
\AA\end{array}$ & $\begin{array}{c}\text { U-anion } \\
\text { length, } \AA\end{array}$ & $\begin{array}{c}\text { U-ligand } \\
\text { length, } \AA\end{array}$ & $\mathrm{O}=\mathrm{U}=\mathrm{O}$ angle \\
\hline $\mathrm{OH}$ & $\mathrm{H}_{2} \mathrm{O}$ & 1.7778 & 2.0060 & 2.3450 & 168.121 \\
\hline & $\mathrm{NH}_{3}$ & 1.7780 & 2.0078 & 2.4979 & 167.681 \\
\hline & $\mathrm{ACN}$ & 1.7762 & 2.0056 & 2.4486 & 167.422 \\
\hline & $\mathrm{ACO}$ & 1.7797 & 2.0133 & 2.2784 & 168.146 \\
\hline & $(\mathrm{ACO})_{2}$ & 1.7890 & 2.0493 & 2.3368 & 172.843 \\
\hline $\mathrm{OCH}_{3}$ & $\mathrm{H}_{2} \mathrm{O}$ & 1.7618 & 2.0167 & 2.4514 & 167.559 \\
\hline & $\mathrm{NH}_{3}$ & 1.7814 & 2.0004 & 2.5031 & 167.652 \\
\hline $\mathrm{H}_{2} \mathrm{O}$ & 1.7735 & 2.3050 & 2.3552 & 171.450 \\
\hline & $\mathrm{NH}_{3}$ & 1.7723 & 2.2884 & 2.4942 & 171.715 \\
\hline
\end{tabular}


1 Table S9. Unscaled frequencies for $\left[\mathrm{UO}_{2}\right]^{2+}$ and $\left[\mathrm{UO}_{2} \mathrm{~A}\right]^{+}$complexes, calculated using B3LYP with the

2 SDD (MWB60) basis set for $\mathrm{U}$, and 6-31+g** for $\mathrm{C}, \mathrm{H}, \mathrm{N}$ and $\mathrm{O}$.

\begin{tabular}{|c|c|c|c|}
\hline A (anion) & $\begin{array}{c}\text { Antisymmetric } \mathrm{O}=\mathrm{U}=\mathrm{O} \\
\text { stretch }\left(v_{3}\right), \mathrm{cm}^{-1}\end{array}$ & $\begin{array}{c}\text { Symmetric } \mathrm{O}=\mathrm{U}=\mathrm{O} \\
\text { stretch }\left(\mathrm{v}_{1}\right), \mathrm{cm}^{-1}\end{array}$ & Other \\
\hline$\left[\mathrm{UO}_{2}\right]^{2+}$ & 1140.17 & - & - \\
\hline $\mathrm{OAc}$ & 1032.31 & 949.82 & $678.71(\mathrm{U}-\mathrm{O})$ \\
\hline $\mathrm{OH}$ & 1025.38 & 945.98 & $1054.43\left(\mathrm{O}-\mathrm{CH}_{3}\right)$ \\
\hline $\mathrm{OCH}_{3}$ & 1010.81 & 923.05 & \\
\hline
\end{tabular}

4 Table S10. Unscaled frequencies for $\left[\mathrm{UO}_{2} \mathrm{AS}\right]^{+}$complexes, calculated using B3LYP with the SDD 5 (MWB60) basis set for $\mathrm{U}$, and 6-31+g** for $\mathrm{C}, \mathrm{H}, \mathrm{N}$ and $\mathrm{O}$.

\begin{tabular}{|c|c|c|c|c|}
\hline A (anion) & S (neutral) & $\begin{array}{c}\text { Antisymmetric } \\
\mathrm{O}=\mathrm{U}=\mathrm{O} \text { stretch } \\
\left(\mathrm{v}_{3}\right), \mathrm{cm}^{-1}\end{array}$ & $\begin{array}{c}\text { Symmetric } \\
\mathrm{O}=\mathrm{U}=\mathrm{O} \text { stretch } \\
\left(\mathrm{v}_{1}\right), \mathrm{cm}^{-1}\end{array}$ & Other \\
\hline \multirow[t]{5}{*}{$\mathrm{OH}$} & $\mathrm{H}_{2} \mathrm{O}$ & 1003.05 & 925.22 & $658.56(\mathrm{U}-\mathrm{OH})$ \\
\hline & $\mathrm{NH}_{3}$ & 999.39 & 922.3 & $656.09(\mathrm{U}-\mathrm{OH})$ \\
\hline & $\mathrm{ACN}$ & 999.23 & 921.31 & $652.34(\mathrm{U}-\mathrm{OH})$ \\
\hline & $\mathrm{ACO}$ & 997.79 & 917.85 & $626.43(\mathrm{U}-\mathrm{OH})$ \\
\hline & $(\mathrm{ACO})_{2}$ & 979.63 & 900.29 & $592.51(\mathrm{U}-\mathrm{OH})$ \\
\hline \multirow[t]{2}{*}{$\mathrm{OCH}_{3}$} & $\mathrm{H}_{2} \mathrm{O}$ & 990.49 & 905.25 & $\begin{array}{c}1079.62(\mathrm{U}- \\
\left.\mathrm{OCH}_{3}\right)\end{array}$ \\
\hline & $\mathrm{NH}_{3}$ & 987.23 & 902.94 & $\begin{array}{c}1080.10(\mathrm{U}- \\
\left.\mathrm{OCH}_{3}\right)\end{array}$ \\
\hline \multirow[t]{2}{*}{ OAc } & $\mathrm{H}_{2} \mathrm{O}$ & 1014.81 & 925.96 & - \\
\hline & $\mathrm{NH}_{3}$ & 1013.37 & 926.16 & - \\
\hline
\end{tabular}


1 Table S11. Bond lengths (Angstroms) and $\mathrm{O}=\mathrm{U}=\mathrm{O}$ bond angles for $\left[\mathrm{UO}_{2}\right]^{2+}$ and $\left[\mathrm{UO}_{2} \mathrm{~A}\right]^{+}$complexes,

2 calculated using B3LYP with the SDD (MWB60) basis set for $\mathrm{U}$, and 6-31+g** for C, H, N and $\mathrm{O}$.

\begin{tabular}{|c|c|c|c|}
\hline A (anion) & $\mathrm{U}=\mathrm{O}$ length, $\AA$ & $\mathrm{U}-\mathrm{O}$ length (U to ligand), $\AA$ & $\mathrm{O}=\mathrm{U}=\mathrm{O}$ angle \\
\hline$\left[\mathrm{UO}_{2}\right]^{2+}$ unligated & 1.7002 & - & 179.578 \\
\hline $\mathrm{OAc}$ & 1.7450 & 2.0104 & 167.409 \\
\hline $\mathrm{OH}$ & 1.7510 & 1.9986 & 167.237 \\
\hline $\mathrm{OCH}_{3}$ & 1.7681 & 1.9835 & 167.555 \\
\hline
\end{tabular}

4 Table S12. Bond lengths (Angstroms) and $\mathrm{O}=\mathrm{U}=\mathrm{O}$ bond angles for $\left[\mathrm{UO}_{2} \mathrm{AS}\right]^{+}$complexes, calculated 5 using B3LYP with the SDD (MWB60) basis set for U, and 6-31+g** for C, H, N and O.

\begin{tabular}{|c|c|c|c|c|c|}
\hline A (anion) & $\mathrm{S}$ (neutral) & $\begin{array}{c}\mathrm{U}=\mathrm{O} \text { length, } \\
\AA\end{array}$ & $\begin{array}{c}\text { U-anion } \\
\text { length, } \AA\end{array}$ & $\begin{array}{c}\text { U-ligand } \\
\text { length, } \AA\end{array}$ & $\mathrm{O}=\mathrm{U}=\mathrm{O}$ angle \\
\hline $\mathrm{OH}$ & $\mathrm{H}_{2} \mathrm{O}$ & 1.7546 & 2.0277 & 2.4416 & 167.606 \\
\hline & $\mathrm{NH}_{3}$ & 1.7581 & 2.0332 & 2.5437 & 167.245 \\
\hline & $\mathrm{ACN}$ & 1.7571 & 2.0318 & 2.4771 & 166.983 \\
\hline & $\mathrm{ACO}$ & 1.7592 & 2.0052 & 2.3252 & 169.898 \\
\hline & $(\mathrm{ACO})_{2}$ & 1.7682 & 2.0828 & 2.3931 & 172.640 \\
\hline $\mathrm{OCH}_{3}$ & $\mathrm{H}_{2} \mathrm{O}$ & 1.7618 & 2.0167 & 2.4514 & 167.559 \\
\hline & $\mathrm{NH}_{3}$ & 1.7633 & 2.0211 & 2.5561 & 167.187 \\
\hline & $\mathrm{H}_{2} \mathrm{O}$ & 1.7735 & 2.2968 & 2.4616 & 171.024 \\
\hline & $\mathrm{NH}_{3}$ & 1.7540 & 2.3015 & 2.5566 & 171.716 \\
\hline
\end{tabular}

6 
Complete citation information for references found in document with more than 10 authors.

2

73) Aprà, E.; Windus, T. L.; Straatsma, T. P.; Bylaska, E. J.; de Jong, W.; Hirata, S.; Valiev, M.; Hackler, M.; Pollack, L.; Kowalski, K.; Harrison, R.; Dupuis, M.; Smith, D. M. A.; Nieplocha, J.; V., T.; Krishnan, M.; Auer, A. A.; Brown, E.; Cisneros, G.; Fann, G.; Fruchtl, H.; Garza, J.; Hirao, K.; Kendall, R.; Nichols, J.; Tsemekhman, K.; Wolinski, K.; Anchell, J.; Bernholdt, D.; Borowski, P.; Clark, T.; Clerc, D.; Dachsel, H.; Deegan, M.; Dyall, K.; Elwood, D.; Glendening, E.; Gutowski, M.; Hess, A.; Jaffe, J.; Johnson, B.; Ju, J.; Kobayashi, R.; Kutteh, R.; Lin, Z.; Littlefield, R.; Long, X.; Meng, B.; Nakajima, T.; Niu, S.; Rosing, M.; Sandrone, G.; Stave, M.; Taylor, H.; Thomas, G.; van Lenthe, J.; Wong, A.; Zhang, Z.; Version 4.7 ed.; Pacific Northwest National Laboratory: Richland, Washington 99352-0999, USA, 2005 (1)

80) Frisch, M. J.; Trucks, G. W.; Schlegel, H. B.; Scuseria, G. E.; Robb, M. A.; Cheeseman, J. R.; Zakrzewski, V. G.; Montgomery, J. A. J.; Stratmann, R. E.; Burant, J. C.; Dapprich, S.; Millam, J. M.; Daniels, A. D.; Kudin, K. N.; Strain, M. C.; Farkas, O.; Tomasi, J.; Barone, V.; Cossi, M.; Cammi, R.; Mennucci, B.; Pomelli, C.; Adamo, C.; Clifford, S.; Ochterski, J.; Petersson, G. A.; Ayala, P. Y.; Cui, Q.; Morokuma, K.; Malick, D. K.; Rabuck, A. D.; Raghavachari, K.; Foresman, J. B.; Cioslowski, J.; Ortiz, J. V.; Stefanov, B. B.; Liu, G.; Liashenko, A.; Piskorz, P.; Komaromi, I.; Gomperts, R.; Martin, R. L.; Fox, D. J.; Keith, T.; Al-Laham, M. A.; Peng, C. Y.; Nanayakkara, A.; Gonzalez, C.; Challacombe, M.; Gill, P. M. W.; Johnson, B.; Chen, W.; Wong, M. W.; Andres, J. L.; Gonzalez, C.; Head-Gordon, M.; Replogle, E. S.; Pople, J. A. Gaussion 98, Revision A.4, Gaussian, Inc.. Pittsburgh, PA, 1998. 